\title{
Dar dikim aralıklarında kurulan kavak (P.x euramericana ve $P$. deltoides klonları) ağaçlandırmalarının ekonomisi
}

\author{
Sacit Koçera* (D), M. Said Kara ${ }^{a}$ (D)
}

\begin{abstract}
Özet: Türkiye'de kavak ağaçlandırmaları, kaliteli (kalın çaplı) kavak odunu üretmek amacıyla, genellikle geniş dikim aralıklarında tesis edilmektedir. Bu çalışmada, daha dar dikim aralıklarında tesis edilen deneysel kavak ağaçlandırmaları kullanılarak, daha kısa idare sürelerinde, daha küçük boyutlu kitlesel odun üretimi modelleri incelenmiștir. Üç ayrı bonitet sınıfındaki ağaçlandırmaların ekonomik analizi, beş değiş̧ik dikim aralığı ve I-214, I-45/51, Samsun (I-77/51), İzmit (S.307-26) ve 89.M.060 olmak üzere, beş farklı kavak klonu için yapılmıștır. Ekonomik analizlerde Net Bugünkü Değer (NBD) ve İç Kârlılık Oranı (IKO) ölçütleri kullanılmıştır. İnce boyutlu kitlesel kavak odunu üretimi için, en yüksek NBD ve İKO, 89.M060 klonunda ve $4,5 \mathrm{~m}^{2} /$ ağaç dikim aralığında elde edilmiştir. Tüm seçenekler için NBD ve IKKO ölçütlerine göre idare süreleri belirlenmiştir. NBD ölçütünde kullanılan faiz oranı değiştikçe idare sürelerinin değiştiği görülmüştür. İKO ölçütüne göre belirlenen idare süreleri, NBD ölçütü ile belirlenenden daha kısa olmaktadır. Bu nedenlerle, endüstriyel ağaçlandırma yatırımlarının değerlendirilmesinde İKO ölçütü kullanılmalıdır. İdare sürelerinin değişik dikim aralıklarına göre, I., II. ve III. bonitet sınıfları için, sırasıyla $6-8,7-9$ ve $8-10$ yıl olması önerilmiştir.
\end{abstract}

Anahtar kelimeler: Kavak, Endüstriyel ağaçlandırma, Dikim aralıkları, İdare süresi, NBD, İKO

\section{Economics of poplar (clones of P.x euramericana ve P. deltoides) plantations established in closer spacings}

\begin{abstract}
At present, majority of commercial poplar plantations aimed at producing quality timbers with larger dimension are established in wider planting spacings in Turkey. The experimental poplar plantations in closer spacings were established for this study purposes in order to investigate the prospects for producing mass quantity of small dimensioned chip wood relatively in shorter period of plantation rotation rather than producing quality timber of larger dimension in longer period of rotation. Along with five various planting spacings, five different poplar clones such as "I-214", "I-45/51", "Samsun (I-77/51)", "Izmit (S.30726)" and "89.M.060" were sampled in the experimental plantation blocks which were repeated on sites of three different growth conditions. The criteria of "Net Present Value (NPV) and "Internal Rate of Return" (IRR) were used for economic analyses. The results of the analyses showed that the most suitable spacing for producing mass quantity of chip wood is " $3 \mathrm{~m} \times 1,5 \mathrm{~m}$ " $\left(4,5 \mathrm{~m}^{2} /\right.$ plant) and most promising poplar clone is "89.M.060". The plantation rotation periods were also determined in accordance with the criteria of NPV and IRR. The period of rotation varied by the variation of the discount rate involved when the NPV criterion is used for the evaluation. The periods of rotation determined in accordance with the IRR criterion are shorter than the period determined in accordance with the NPV criterion. Therefore, the IRR criterion should be preferred for the evaluation of industrial plantation investments. According to the results of the analyses, the recommended period of plantation rotation varies between 6 to 8 years on good sites, 7 to 9 years on medium sites and 8 to 10 years on poor sites.

Keywords: Poplar, Industrial plantations, Closer spacings, Rotation period, NPV, IRR
\end{abstract}

\section{Giriş}

II. Dünya Savaşı sırası ve sonrasında, hızlı nüfus artışı ve ülkelerin yüksek oranlı büyümeleri, dünyadaki enerji ve değişik hammadde taleplerini artırmıştır. Benzer gelişme odun hammaddesi için de yaşanmıştır. Ancak, devasa boyutlardaki odun hammaddesi talep artışının doğal ormanlardan karşılanamayacağı anlaşılmış ve ince çaplı kitlesel odun üretimine yönelik endüstriyel ormancılık uygulamaları yaygınlaşmaya başlamıştır. Başta kavak olmak üzere söğ̈̈t, okaliptüs, bazı çam türleri gibi, hızlı gelişen orman ağacı türleriyle endüstriyel ormancılığın ve ağaçlandırmaların geliştirilmesi önem kazanmıştır. Ülkeler, doğal ormanlardan nitelikli hammadde temini yerine, endüstriyel ağaçlandırmalardan kitlesel ince çaplı odun hammaddesi teminine dayalı üretim modellerini geliştirmişlerdir. Halen Birleşmiş Milletler Gıda ve Tarım Örgütü (FAO) bünyesinde çalışmalarını yürüten Uluslararası Kavak Komisyonu (IPC) 1947 yılında kurulmuştur. Ülkemizde de, Türkiye Milli Kavak Komisyonu (TMKK) kurulmuş ve TBMM kararıyla 1955 yılında IPC'ye üye olmuştur. Sürecin devamında, IPC'nin de katılımıyla alınan bir dizi karar uyarınca, Kavakçılık Araştırma Enstitüsü 1962 yılında çalışmalara başlamıştır. Ülkemizde 1960'lı yıllardan beri yapılan toplantılarda, devletimizin hazırlamış olduğu dokümanlarda (DPT, Şura Kararları, Kongre Kararları vb.), endüstriyel ağaçlandırmalara önem verilmesi gerektiği belirtilmesine
凶 a Kavak ve Hızlı Gelişen Orman Ağaçları Araştırma Enstitüsü Müdürlüğü, Kocaeli

Corresponding author (İletişim yazarı): sacitkocer@ogm.gov.tr

$\checkmark$ Received (Geliş tarihi): 08.06.2021, Accepted (Kabul tarihi): 23.08.2021
Citation (Atıf): Koçer, S., Kara, M.S., 2021. Dar dikim aralıklarında kurulan kavak (P.x euramericana ve $P$. deltoides klonlar1) ağaçlandırmalarının ekonomisi. Turkish Journal of Forestry, 22(3): 257-270 DOI: $10.18182 /$ tif. 949462 
rağmen, beklenen gelişme sağlanamamış, hammadde yetersizliği kağıt fabrikalarımızın kapatılmasının ana sebeplerinden biri olmuştur.

Kısa idare sürelerinde daha yüksek miktarda hammadde üretilebilmesi, dünyada kültürünün bilinmesi, elde edilen odununun geniş kullanım alanının bulunması, 1slah ve melezleme çalışmalarına uygun olması, değişik coğrafyalardaki toprak ve iklim koşullarına uyum sağlayan farklı tür ve klonlarının bulunabilmesi gibi nedenlerle, kavak cinsi endüstriyel ağaçlandırmalarda yaygın olarak kullanılmaktadır.

Ülkemizde Karakavak dışındaki, yabancı kavak kültürü çalışmaları ilk kez Sümerbank Selüloz ve Kağıt Sanayii (SEKA) tarafından 1946 yılında başlatılmıştır (Birler, 2010). Yabancı kavak klonu kültür çalışmaları ve yetiştirme teknikleri, o zamanki teknolojiye ve kavak odununa olan talep yapısına göre şekillenmiş, kaliteli ve kalın çaplı kavak odunu üretimine yönelik ve geniş dikim aralıklarının uygulandığı üretim sistemi benimsenmiş ve yerleşmiştir.

Endüstri, tüketim alanı ile ilgili değil, üretim sistemi ile ilgili bir kavramdır. Endüstriyel ağaçlandırmalar, kitlesel odun hammaddesi üretimine yönelik hızlı gelişen ağaç türleri ile kurulan ticari amaçlı yatırımlardır (Koçer, 2006). Endüstri, belirli bir süreçte, sermaye yoğun teknoloji (1slah edilmiş materyal, mekanizasyon, sulama vb.) kullanarak, bir maddenin, enerjinin veya gücün niteliğini ve/veya biçimini değiştirerek kitlesel üretimde bulunma faaliyetidir. 20. yüzyılın üçüncü çeyreğinde, orman ürünleri endüstrisi, doğal ormanlardan arz edilen emvale dayalı teknolojiye sahipken, orman ürünleri arz ve talep yapısındaki değişimlere paralel olarak, özellikle dördüncü çeyrekten sonra, orman endüstrisinin üretim sistemleri ve teknolojileri de yenilenmeye başlamıştır.

Ülkemizde de bu gelişmelere paralel bir durum yaşanmıştır. 2000'li yılların başından itibaren Türkiye levha sektörünün yatırımları büyük boyutlara ulaşmış, Avrupa ve Dünya üretim kapasitesi içerisindeki yeri ve önemi artmıştır. Anılan gelişmelere bağlı olarak, ince çaplı odun hammaddesine olan iç talep devasa düzeye çıkmıştır. Levha sektörünün en önemli odun hammaddesi girdilerinden birisini de kavak odunu oluşturmaktadır. Levha sektörünün 2018 yılı içerisinde yaklaşı 700 bin ton kavak odunu tükettiği bildirilmektedir (Dedebaş, 2019). Bu miktar yaklaşı ince çaplı 1 milyon $\mathrm{m}^{3}$ odun hammaddesine karşılık gelmektedir. Bu miktarda ince çaplı kavak odunu

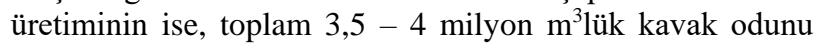
üretiminden elde edilmesi mümkündür. İnce çaplı odun hammaddesi üretimini artırmak, hem ithal ikamesi, hem doğal ormanlar üzerindeki üretim baskısını azaltması için bir zorunluluk haline gelmiştir. Bu nedenle, yerli levha sektörünün talebini karşllayabilmek ve kağıt sektörünü yeniden canlandırmak için daha fazla kavak odunu üretebilmek gereklidir. Bu kapsamda, daha kısa idare sürelerinde, levha ve kağıt sektörünün talebine uygun ince çaplı emval üretiminin artırılması yollarından hangisinin veya hangilerinin daha ekonomik olduğunun araştırılması gerekmektedir. Bu çalışma, ince çaplı kavak odun üretimi modellerinin geliştirilmesi ve uygulamaya konulması amacıyla yürütülmüştür.

Dünyada 2017 yılında orman ürünleri dış ticaret hacmi yaklaşık 250 milyar \$ civarındadır. Çin, orman ürünleri dış ticaretinde yaklaşık 34,5 milyar $\$$ açı vermektedir. Bu nedenle Çin, Dünya'da hem kavak hem de diğer türlerle tesis edilen ağaçlandırmaların \%25'ini tek başına yapmaktadır. Endüstriyel ağaçlandırmaların büyüklüğü toplam orman alanının \%9'unu oluşturmakla birlikte, toplam odun üretimi içerisindeki payı \%46 düzeyine ulaşmıştır. Ülkemizin 2017 yılındaki orman ürünleri ithalat tutarı yaklaşık 4,3 milyar \$ kadardır. Bunun yaklaşık 3,1 milyar \$'ını kağıt ürünleri ve hamuru, 420 milyon \$'ını levha ve 191 milyon \$’lık bölümünü ise yonga ithalatı oluşturmaktadır. Ülkemizin 2017 yılındaki orman ürünleri ithalatının yapısı Çizelge 1 ve Şekil 1'de verilmiştir (FAO, 2018; 2019).

Şekil 1'de görüldüğü üzere, toplam ithalatın önemli bir bölümü mamul ve yarımamul ürünlerdir. Üstelik bu ürünlerin hammaddesinin \%89 kadarlık önemli bölümü endüstriyel ormancılık ve ağaçlandırmalardan sağlanabilen ürünlerdir. Dolayısıyla orman ürünleri ithalatında ilk 20 ülke arasında yer alan ve kendi kaynaklarını kullanamayan Türkiye'den önemli tutarda katma değer transferi yapılmaktadır. Örneğin, hammadde niteliğindeki yuvarlak oduna ödenen ithalat tutarının giderek azaldığ 1 , ancak yuvarlak odunu ikame eden yarı mamul niteliğindeki biçilmiş ürün (kereste) ithalatına ödenen tutarın giderek arttığı belirlenmiştir (Akkaya vd., 2020). Kağıt ürünleri ve panelden oluşan mamul ürün bölümü ise toplam ithalatın yaklaşık 2/3'ünü oluşturmaktadır.

Çizelge 1. Ülkemizin 2017 yılındaki orman ürünleri ithalatı

\begin{tabular}{|c|c|c|c|c|}
\hline Ürün çeşidi & Milyon \$ & Toplam & $\%$ & $\begin{array}{c}\text { Hammadde } \\
\text { kaynağ } 1\end{array}$ \\
\hline Yuvarlak odun & 39 & \multirow{4}{*}{464} & \multirow{4}{*}{11} & \multirow{4}{*}{ Diğer } \\
\hline Odun kömürü & 39 & & & \\
\hline Atık kağıt & 146 & & & \\
\hline Kereste & 240 & & & \\
\hline Diğer & 52 & \multirow{5}{*}{3807} & \multirow{5}{*}{89} & \multirow{5}{*}{$\begin{array}{l}\text { Endüstriyel } \\
\text { ağaçlandırma }\end{array}$} \\
\hline Yonga & 191 & & & \\
\hline Panel & 420 & & & \\
\hline Kağıt hamuru & 799 & & & \\
\hline Kağıt ürünleri & 2345 & & & \\
\hline Toplam & 4271 & 4271 & 100 & \\
\hline
\end{tabular}

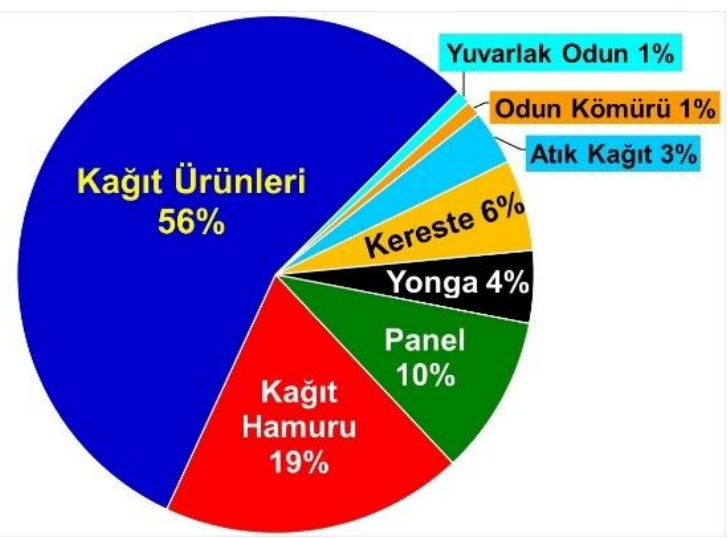

Şekil 1. Ülkemizin 2017 yılındaki orman ürünleri ithalatının yapısı 


\section{Materyal ve yöntem}

\subsection{Materyal}

Çalışmada, dördü ülkemizde ticari olarak tescil edilmiş beş adet kavak klonu kullanılmıştır. Bu klonlardan I-214 ve I-45/51 klonları euramericana, geriye kalan Samsun, İzmit ve 89.M.060 klonları $P$. deltoides melezleridir.

Farklı kavak dikimlerinin ekonomik analizlerin yapılabilmesi için, oluşan gider ve gelirlerin bilinmesi gerekmektedir. Giderler kavak ağaçlandırmalarında yürütülen standart işlemler dikkate alınarak belirlenmiştir. İnce çaplı odun üretimini amaçlayan kavak işletmeciliğinde giderlerin belirlenmesinde, kaliteli odun üretim amaçlı ağaçlandırmalarda uygulanan budama ve tepe düzeltme işlemleri, standart işlemler arasından çıkarılmıştır. Ayrıca ağaçlandırmaların tesisinde kaliteli emval üretiminin amaçlanmaması ve maliyetlerin azaltılması için, fidan ve sırık çeliği yerine, gövde çeliği dikim materyali olarak seçilmiştir. Bu nedenle, fidan dağıtımı, dikim çukurlarının açılması, fidan dikimi gibi işlemler girdi unsurları arasına dahil edilmemiştir. Ağaçlandırmaların tesisinde kullanılan dikim materyali, aynı nitelik ve niceliklerde olduğu için, tesis maliyetleri beş değişik dikim sıklı̆̆ına $\left(4,5 \mathrm{~m}^{2}, 6,0 \mathrm{~m}^{2}\right.$, $9 \mathrm{~m}^{2}, 12 \mathrm{~m}^{2}$ ve $15 \mathrm{~m}^{2}$ ) göre ayrı ayrı hesaplanmıştır.

Kavak ağaçlandırmalarında gelirlerin belirlenmesi için odun hasılalarının bilinmesi gerekmektedir. Kavak ağaçlandırmalarından elde edilebilecek odun hasıla miktarları, klon çeşidine, bonitet sınıfına ve dikim sıklığına göre farklılık göstermektedir. Bu nedenle, çalışmaya konu olan kavak klonlarının üç bonitet sınıfı ve beş dikim sıklığına göre, Koçer vd. (2020) tarafından hazırlanmış olan "değişken sıklık hasılat tabloları" ve bu tablolarda yer alan yongalık odun miktarlarından yararlanarak hasılalar belirlenmiştir. Yararlanılan hasılat tablolarından bir tanesi, Çizelge 2'de örnek olarak verilmiştir.

\subsection{Yöntem}

Kavak ağaçlandırmaları, ticari kazanç sağlamak için, kavak odunu üretimini amaçlayan yatırımlardır. $\mathrm{Bu}$ yatırımlarda tek amaç kâr etmek olduğu için, ülkemizde kavak ağaçlandırmalarının çok büyük çoğunluğu, özel kişi ya da kurumlar tarafından gerçekleştirilmektedir. $\mathrm{Bu}$ nedenle, kavak ağaçlandırmaları sulanabilir ve verimliliği yüksek ovaların bulunduğu havzalarda yaygınlaşmıştır. Kavak ağaçlandırmaları, tarımsal üretime alternatif olduğu için, girişimciler en az tarımsal üretimden sağlayabilecekleri kadar kâra, faydaya ulaşmak durumundadır. Bu nedenle, kavak ağaçlandırmalarındaki ticari kârlılık ve başarı düzeyi, yatırımlara karar vermede etkili olmaktadır.

Ticari kârlılık analizlerinde, projenin net finansal sonuçlarına göre, işletmenin kârlılığının parasal olarak belirlenmesi amaçlanmaktadır. Ticari kârlılık analizleri Basit Kârlılık Oranı, Geri Ödeme Süresi, Net Bugünkü Değer, Net Fayda Maliyet Oranı, İç Kârlılık Oranı ölçütleri kullanılarak yapılmaktadır (UNIDO, 1977). Kârlılık analizinde kullanılabilen basit kârlılık oranı ve geri ödeme süresi ölçütleri, projenin ömrünü ve nakit akımının oluştuğu zamanı dikkate almayan, basit ve statik nitelikte ölçütlerdir (Geray, 1986). Bu nedenle, anılan iki ölçüt çalışmada kullanılmamıştır. Kavak ağaçlandırma yatırımlarının kârlılığını belirlemek için, Net Bugünkü Değer (NBD) ve İç Kârlılık Oranı (IKKO) karar ölçütleri olarak seçilmiştir.
Çizelge 2. 89.M.060 klonu için hasılat tablosu Bonitet Sınıfı:1, Dikim Sıklığı: 4,5 m2/ağaç - 2222 ağaç/ha

\begin{tabular}{rrrrrrrr}
\hline & \multicolumn{3}{c}{ Orta ağaç } & \multicolumn{4}{c}{ Meşcere } \\
\cline { 2 - 8 } Yaş & $\begin{array}{c}\text { Göğüs } \\
\text { çap1 }\end{array}$ & $\begin{array}{c}\text { Tam } \\
\text { boyu }\end{array}$ & Hacmi & $\begin{array}{c}\text { Ağaç } \\
\text { hacmi } \\
(\mathrm{cm})\end{array}$ & $\begin{array}{c}\text { Yongalık } \\
\text { odun } \\
\text { hacmi } \\
\left(\mathrm{dm}^{3}\right)\end{array}$ & $\begin{array}{c}\text { Genel } \\
\text { ortalama } \\
\text { artım } \\
\left(\mathrm{m}^{3} / \mathrm{ha}\right)\end{array}$ & $\begin{array}{c}\text { Y1llık } \\
\text { cari } \\
\text { artım }\end{array}$ \\
\hline 3 & 9,5 & 10,3 & 39,3 & 87,3 & 77,9 & 29,092 & 61,996 \\
4 & 12,1 & 14,2 & 80,0 & 177,8 & 167,5 & 44,452 & 90,533 \\
5 & 14,0 & 17,1 & 124,0 & 275,5 & 264,0 & 55,095 & 97,664 \\
6 & 15,4 & 19,2 & 165,1 & 366,8 & 354,2 & 61,132 & 91,318 \\
7 & 16,5 & 20,8 & 201,1 & 446,9 & 433,2 & 63,846 & 80,128 \\
8 & 17,4 & 22,0 & 232,0 & 515,5 & 500,8 & 64,441 & 68,613 \\
9 & 18,0 & 22,9 & 258,3 & 574,0 & 558,3 & 63,775 & 58,442 \\
10 & 18,6 & 23,6 & 280,8 & 623,9 & 607,4 & 62,395 & 49,972 \\
11 & 19,1 & 24,1 & 300,2 & 667,0 & 649,8 & 60,638 & 43,074 \\
12 & 19,5 & 24,5 & 317,1 & 704,5 & 686,6 & 58,709 & 37,488 \\
\hline
\end{tabular}

\subsubsection{Net Bugünkü Değer (NBD)}

NBD, bir projenin ömrü boyunca gerçekleşecek net nakit akışını, paranın zaman değerini dikkate alarak, belli bir yıla (genellikle sıfır yılına) ve önceden belirlenmiş bir faiz oranı ile indirgeyerek belirlenmektedir (Eşitlik 1-2). Bugüne indirgenmiş net değerler, sıfırdan büyük veya eşit $(\mathrm{NBD} \geq 0)$ ise proje kabul edilmektedir (Geray, 1986).

$$
\begin{aligned}
& N B D=\sum_{t=1}^{n}(C I-C O)_{t} \alpha_{t} \\
& N B D=\sum_{t=1}^{n} C I_{t} \alpha_{t}-\sum_{t=1}^{n} C O_{t} \alpha_{t}
\end{aligned}
$$

$\mathrm{CI}_{\mathrm{t}} \quad$ : t yıllarındaki gelirler

$\mathrm{CO}_{\mathrm{t}}$ : $\mathrm{t}$ yıllarındaki giderler

$\propto_{\mathrm{t}} \quad$ : Seçilen faiz oranı $(\mathrm{p})$ ve zamana ( $\mathrm{t}$ ) göre oluşan indirgeme oranı

Seçilen faiz (getiri, iskonto, indirgeme) oranının, ilgili sektörün koşullarına uygun ve olabildiğince sermaye piyasasındaki faiz oranlarına yakın olması gerekmektedir. Eğer yatırım borç alınarak yapılmış ise, ödenen faiz oranı indirgeme oranı olarak kullanılmaktadır (Geray, 1986). Bu çalışmada, faiz oranı $\% 8$ olarak seçilmiştir. Ayrıca \%6, \%10 ve $\% 12$ faiz oranları için duyarlılık analizi yapılmıştır.

NBD ölçütü, indirgeme oranının önceden bilinmesini zorunlu kılmaktadır. Ancak bu oran zamana ve sektöre göre değişebildiği için, belirlenmesi güç olmakta ve öznel yanı bulunmaktadır. Bunun yanında NBD proje büyüklügünden de etkilenmektedir.

\subsection{2. İ̧̧ Kârlılık Oranı (IKKO)}

İKO ölçütünde, NBD'den farklı olarak, bir faiz oranı hesaplanmak istenmektedir. Projenin bugüne indirgenmiş gelirlerini ve giderlerini birbirine eşitleyen veya net nakit akışını sıfır yapan, yani NBD'yi sıfıra eşitleyen faiz oranı belirlenmektedir (Eşitlik 3-4). Elde edilen bu faiz oranına İKO denilmektedir. İKO, yatırılan sermayenin kârlılığını yansıtmakta ve projenin borçlanmalarda ödeyebileceği en yüksek faiz oranının kaç olması gerektiğini göstermektedir (UNIDO, 1977; Geray, 1986).

$$
\begin{aligned}
& N B D=0=\sum_{t=1}^{n}(C I-C O)_{t} \alpha_{t} \\
& \sum_{t=1}^{n} C I_{t} \alpha_{t}=\sum_{t=1}^{n} C O_{t} \alpha_{t}
\end{aligned}
$$

İKO, içinde bulunulan koşullara göre baz alınabilecek herhangi bir faiz oranından, yatırılan sermayenin ödenmesini gösteren asgari kabul edilebilir oranı ifade eden 
sınır bir orandan ya da eğer proje borç alınarak yapılacak ise, borca uygulanan faiz oranından büyük ise proje kabul edilmektedir (UNIDO, 1977; Geray, 1986). İKO ölçütü, projenin büyüklüğünden etkilenmemekte, bu yönüyle farklı seçeneklerin karşılaştırılmasında tercih edilmektedir. Ancak İKO ölçütü alternatif projelerin yatırım için gerekli fon düzeyini dikkate almamakta, en yüksek İKO’ya sahip proje seçilmektedir. Yüksek düzeyde fon bulunması durumunda, seçilen proje, eğer düşük düzeyde yatırım gerektiriyorsa, girişimcinin elinde atıl fon kalma riski veya yeniden yatırım riski bulunmaktadır.

\section{Bulgular}

Kavak ağaçlandırmalarında yatırım süresi, ağaçlandırmanın tesisinden kesim zamanına kadar geçen süredir. Girdiler, ağaçlandırmanın tesisinden idare süresi sonuna kadar yürütülen işlemlerin maliyetlerinin toplamından oluşmaktadır. Çıktılar ise, varsa ara hasıla ve idare süresi sonunda elde edilen odun hasılasının toplam parasal karşılı̆̆ 1 kadar olmaktadır. Üretim modelinde herhangi bir odun veya ara tarım kaynaklı ara hasıla olmadığı öngörülmüştür. Odun hasıla miktarları ve ürün çeşitleri bonitet sınıfı, dikim sıklığı ve yaş basamağına göre değişmektedir. Levha ve kağıt sektörünün talebine uygun odun hammaddesi üretim modelinin ortaya konulması amaçlandığından, kaliteli emval yerine ince çaplı emval üretileceği, yani yongalık odun elde edileceği kabul edilmiştir. Gelirler hasılat tablolarında verilen yongalık odun miktarı ile odun birim fiyatı çarpılarak belirlenmiştir.

Kavak ağaçlandırma maliyetleri, kullanılan materyal ve yürütülen işlemlerin nitelikleri ve maliyetleri aynı olduğu için, klonlara ve bonitet sınıflarına göre değişmemektedir. Dolayısıyla girdiler, beş farklı dikim sıklığı ve değişik yaş basamaklarına göre belirlenmiştir.

\subsection{Girdiler}

Kavak ağaçlandırmasının tesisinden kesimine kadar, idare süresi boyunca yürütülen standart işlemlerin maliyetleri girdileri oluşturmaktadır. Kaliteli odun üretimini amaçlayan ve geniş dikim aralıklarında kurulan kavak ağaçlandırmaları için yürütülmesi gereken standart işlemler belirlenmiştir (Birler vd., 1989). Belirlenen standart işlemler arasında, kaliteli odun üretim miktarını artırmayı amaçlayan kültür ve bakım işlemleri bulunmaktadır. Bu çalışmada ince çaplı odun üretimi amaçlandığ 1 için, odun kalitesini artırmayı amaçlayan, "tepe düzeltme" ve "budama" işlemleri standart işlemler arasından çıkarılmıştır.

Klasik kavak ağaçlandırmalarının kurulmasında 1 veya 2 yaşlı fidan veya sırık çeliği kullanılmaktadır. Bu çalışmanın odun hasılasının elde edildiği denemelerin tesisinde $20-25$ $\mathrm{cm}$ uzunluğundaki gövde çelikleri kullanıldığı için, klasik kavak ağaçlandırmalarının tesisinde yürütülen "fidan dikim çukurlarının açılması", "dikim çukurlarında gübreleme”, “dikim çukurlarına gübre nakli” ve "fidan dikimi” işlemleri, standart işlemler arasından çıkarılmıştır. Bu işlemlerin yerine "gövde çeliği dikimi" standart işlem olarak belirlenmiş ve materyal maliyeti için fidan veya sırık çeliği bedeli değil, gövde çeliği bedeli alınmıştır.

Orman Genel Müdürlüğü (OGM) tarafindan her yıl "Ağaçlandırma, Rehabilitasyon, Toprak Muhafaza, Erozyon ve Sel Kontrolü, Mera Islahı, Fidanlık Çalışmaları, Silvikültür ve Etüt Proje İşlerine Ait Birim Fiyat Cetveli” yayınlanmaktadır. İşlemlerin maliyetlerinin belirlenmesinde, 2019 yılına ait birim fiyatlar kullanılmıştır (OGM, 2019).

İnce çaplı kavak odunu üretimini amaçlayan ve dar dikim aralıklarında kurulan kavak ağaçlandırmalarında yürütülen standart işlemler ve yıllık yineleme sayıları Çizelge 3'te verilmiştir.

Çizelge 3'te görüldüğü üzere, 7. yaştan itibaren, ağaç kökleri taban suyuna ulaştığı için, sulama gereksinimi ortadan kalkmaktadır. Kavak meşceresinde kapalılık oluşması ve gölgeleme etkisi nedeniyle, bakım sürümü ve diskaro çekme işlemlerinin yürütülmesine gerek duyulmamaktadır. Ağaç diplerinde ot alma çapa işleminin ilk üç yıl yürütülmesi yeterli olmaktadır.

OGM tarafindan yayınlanan birim maliyetler bazı işlemlerde adet üzerinden hesaplanmaktadır. $\mathrm{Bu}$ nedenle, işlem birim maliyetleri dikim aralıklarına göre ayrı ayrı hesaplanmış ve Çizelge 4'te verilmiştir.

Y1llı işlem maliyetleri, her bir dikim aralığı için, işlemlerin yıllara göre yineleme sayıları (Çizelge 3) ile birim maliyetleri (Çizelge 4) çarpılarak belirlenmiştir. Yıllık maliyetleri belirlemek için, yürütülen işlemlerin y1llık toplamlarının \%10'u kadar beklenmeyen giderlerin olması öngörülmüştür. Dikim aralıklarına göre yıllık işlem maliyetleri Çizelge 5-9'da verilmiştir. Dar dikim aralığında tesis edilen kavak ağaçlandırmalarındaki yıllık maliyetler, dikim aralıklarına göre Çizelge 10'da özetlenmiştir.

Çizelge 3. Standart işlemlerin yineleme sayıları

\begin{tabular}{lccccccccc}
\multirow{2}{*}{\multicolumn{1}{c}{ İşlemler }} & \multicolumn{7}{c}{$\begin{array}{c}\text { Ağaçlandırma yaşı ve } \\
\text { işlem yineleme sayısı }\end{array}$} \\
\cline { 2 - 9 } & 1 & 2 & 3 & 4 & 5 & 6 & 7 & 8 \\
\hline Tam alan çapraz derin sürüm & 1 & - & - & - & - & - & - & - \\
Tam alan diskaro çekme & 1 & - & - & - & - & - & - & - \\
Dikim yerlerinin işaretlenmesi & 1 & - & - & - & - & - & - & - \\
Gövde çeliği bedeli & 1 & - & - & - & - & - & - & - \\
Gövde çeliği dikimi & 1 & - & - & - & - & - & - & - \\
\hline Sulama (İşçi ile) & 4 & 3 & 3 & 3 & 2 & 2 & 1 & - \\
Ağaç diplerinde ot alma ve çapa & 3 & 2 & 2 & - & - & - & - & - \\
Tek yönlü bakım sürümü & 2 & 2 & 2 & 2 & 1 & 1 & 1 & - \\
Tek yönlü diskaro çekme & 2 & 2 & 2 & 2 & 1 & 1 & 1 & - \\
\hline
\end{tabular}


Çizelge 4. Standart işlemlerin birim maliyetleri

\begin{tabular}{|c|c|c|c|c|c|c|c|c|c|}
\hline \multirow{3}{*}{$\begin{array}{l}\text { İşin } \\
\text { türü }\end{array}$} & \multirow{3}{*}{ İ şl e $\mathrm{m} 1$ e $\mathrm{r}$} & \multirow{3}{*}{$\begin{array}{c}\mathrm{Poz} \\
\text { no. }\end{array}$} & \multirow{3}{*}{ Birimi } & \multirow{3}{*}{$\begin{array}{l}\text { Birim } \\
\text { fiyatı }\end{array}$} & \multicolumn{5}{|c|}{ Dikim aralığı (Ağaç sayısı) ad/ha } \\
\hline & & & & & 4,5 & 6,0 & 9,0 & 12,0 & 15,0 \\
\hline & & & & & 2222 & 1667 & 1111 & 833 & 667 \\
\hline \multirow{5}{*}{ Dikim } & Tam alan çapraz derin sürüm & 2001.1 & ha & 485,60 & 485,60 & 485,60 & 485,60 & 485,60 & 485,60 \\
\hline & Tam alan çift yönlü diskaro çekme & 2002.1 & ha & 279,07 & 279,07 & 279,07 & 279,07 & 279,07 & 279,07 \\
\hline & Dikim yerlerinin işaretlenmesi & 2003.1 & 1000 adet & 273,85 & 608,49 & 456,51 & 304,25 & 228,12 & 182,66 \\
\hline & Gövde çeliği bedeli & 3601.1 & 1000 adet & 250,00 & 555,50 & 416,75 & 277,75 & 208,25 & 166,75 \\
\hline & Gövde çeliği dikimi & 3602.1 & 1000 adet & 74,76 & 166,12 & 124,62 & 83,06 & 62,28 & 49,86 \\
\hline \multirow{4}{*}{ Bakım } & Sulama (İşçi ile) & 2104.1 & ha & 144,44 & 144,44 & 144,44 & 144,44 & 144,44 & 144,44 \\
\hline & Ağaç diplerinde ot alma ve çapa & 2103.1 & 1000 adet & 166,79 & 370,61 & 278,04 & 185,30 & 138,94 & 111,25 \\
\hline & Tek yönlü bakım sürümü & 2101.2 & ha & 237,24 & 237,24 & 237,24 & 237,24 & 237,24 & 237,24 \\
\hline & Tek yönlü diskaro çekme & 2102.2 & ha & 136,76 & 136,76 & 136,76 & 136,76 & 136,76 & 136,76 \\
\hline
\end{tabular}

Çizelge 5. Kavak ağaçlandırmalarında $3 \mathrm{~m}$ x 1,5m dikim sıklığı için yıllık işlem maliyetleri

\begin{tabular}{|c|c|c|c|c|c|c|c|c|c|c|}
\hline \multirow{2}{*}{ İşlemler } & \multirow{2}{*}{$\begin{array}{c}\text { Birim } \\
\text { maliyet } \\
\text { (TL/ha) }\end{array}$} & \multicolumn{8}{|c|}{ Yaş sınıfları ve yıllık işlem maliyetleri (TL/ha) } & \multirow{2}{*}{$\begin{array}{c}\text { İşlem } \\
\text { toplamı } \\
\text { (TL/ha) }\end{array}$} \\
\hline & & 1 & 2 & 3 & 4 & 5 & 6 & 7 & $8-12$ & \\
\hline Tam alan çapraz derin sürüm & 485,60 & 486 & 0 & 0 & 0 & 0 & 0 & 0 & 0 & 486 \\
\hline Tam alan çift yönlü diskaro çekme & 279,07 & 279 & 0 & 0 & 0 & 0 & 0 & 0 & 0 & 279 \\
\hline Dikim yerlerinin işaretlenmesi & 608,49 & 608 & 0 & 0 & 0 & 0 & 0 & 0 & 0 & 608 \\
\hline Gövde çeliği Bedeli & 555,50 & 556 & 0 & 0 & 0 & 0 & 0 & 0 & 0 & 556 \\
\hline Gövde çeliği Dikimi & 166,12 & 166 & 0 & 0 & 0 & 0 & 0 & 0 & 0 & 166 \\
\hline Sulama (İşçi ile) & 144,44 & 578 & 433 & 433 & 433 & 289 & 289 & 144 & 0 & 2.600 \\
\hline Ağaç diplerinde ot alma ve çapa & 370,61 & 1112 & 741 & 741 & 0 & 0 & 0 & 0 & 0 & 2.594 \\
\hline Tek yönlü bakım sürümü & 237,24 & 474 & 474 & 474 & 474 & 237 & 237 & 237 & 0 & 2.610 \\
\hline \multirow[t]{2}{*}{ Tek yönlü diskaro çekme } & 136,76 & 274 & 274 & 274 & 274 & 137 & 137 & 137 & 0 & 1.504 \\
\hline & ra toplam & 4532 & 1923 & 1923 & 1181 & 663 & 663 & 518 & 0 & 11.403 \\
\hline \multirow{2}{*}{\multicolumn{2}{|c|}{$\begin{array}{r}\text { Beklenmeyen giderler }(\% 10) \\
\text { Y1llı maliyet toplamı (TL/ha) }\end{array}$}} & 453 & 192 & 192 & 118 & 66 & 66 & 52 & 0 & 1.140 \\
\hline & & 4986 & 2115 & 2115 & 1299 & 729 & 729 & 570 & 0 & 12.543 \\
\hline
\end{tabular}

Çizelge 6. Kavak ağaçlandırmalarında $3 \mathrm{~m}$ x $2 \mathrm{~m}$ dikim sıklığı için yıllık işlem maliyetleri

\begin{tabular}{|c|c|c|c|c|c|c|c|c|c|c|}
\hline \multirow{2}{*}{ İşlemler } & \multirow{2}{*}{$\begin{array}{c}\text { Birim } \\
\text { maliyet } \\
\text { (TL/ha) }\end{array}$} & \multicolumn{8}{|c|}{ Yaş sınıfları ve yıllık işlem maliyetleri (TL/ha) } & \multirow{2}{*}{$\begin{array}{c}\text { İşlem } \\
\text { toplamı } \\
\text { (TL/ha) }\end{array}$} \\
\hline & & 1 & 2 & 3 & 4 & 5 & 6 & 7 & $8-12$ & \\
\hline Tam alan çapraz derin sürüm & 485,60 & 486 & 0 & 0 & 0 & 0 & 0 & 0 & 0 & 486 \\
\hline Tam alan çift yönlü diskaro çekme & 279,07 & 279 & 0 & 0 & 0 & 0 & 0 & 0 & 0 & 279 \\
\hline Dikim yerlerinin işaretlenmesi & 456,51 & 457 & 0 & 0 & 0 & 0 & 0 & 0 & 0 & 457 \\
\hline Gövde çeliği bedeli & 416,75 & 417 & 0 & 0 & 0 & 0 & 0 & 0 & 0 & 417 \\
\hline Gövde çeliği dikimi & 124,62 & 125 & 0 & 0 & 0 & 0 & 0 & 0 & 0 & 125 \\
\hline Sulama (İşçi ile) & 144,44 & 578 & 433 & 433 & 433 & 289 & 289 & 144 & 0 & 2.600 \\
\hline Ağaç diplerinde ot alma ve çapa & 278,04 & 834 & 556 & 556 & 0 & 0 & 0 & 0 & 0 & 1.946 \\
\hline Tek yönlü bakım sürümü & 237,24 & 474 & 474 & 474 & 474 & 237 & 237 & 237 & 0 & 2.610 \\
\hline \multirow[t]{2}{*}{ Tek yönlü diskaro çekme } & 136,76 & 274 & 274 & 274 & 274 & 137 & 137 & 137 & 0 & 1.504 \\
\hline & ra toplam & 3922 & 1737 & 1737 & 1181 & 663 & 663 & 518 & 0 & 10.423 \\
\hline Beklen & $\operatorname{ler}(\% 10)$ & 392 & 174 & 174 & 118 & 66 & 66 & 52 & 0 & 1.042 \\
\hline Y1llik ma & 11 (TL/ha) & 4315 & 1911 & 1911 & 1299 & 729 & 729 & 570 & 0 & 11.465 \\
\hline
\end{tabular}

Çizelge 7. Kavak ağaçlandırmalarında $3 \mathrm{~m}$ x 3m dikim sıklığ 1 için yıllık işlem maliyetleri

\begin{tabular}{|c|c|c|c|c|c|c|c|c|c|c|}
\hline \multirow[b]{2}{*}{ İşlemler } & \multirow{2}{*}{$\begin{array}{c}\text { Birim } \\
\text { Maliyet } \\
\text { (TL/ha) }\end{array}$} & \multicolumn{8}{|c|}{ Yaş sınıfları ve yıllık işlem maliyetleri (TL/ha) } & \multirow{2}{*}{$\begin{array}{l}\text { İşlem } \\
\text { toplamı } \\
\text { (TL/ha) }\end{array}$} \\
\hline & & 1 & 2 & 3 & 4 & 5 & 6 & 7 & $8-12$ & \\
\hline Tam alan çapraz derin sürüm & 485,60 & 486 & 0 & 0 & 0 & 0 & 0 & 0 & 0 & 486 \\
\hline Tam alan çift yönlü diskaro çekme & 279,07 & 279 & 0 & 0 & 0 & 0 & 0 & 0 & 0 & 279 \\
\hline Dikim yerlerinin işaretlenmesi & 304,25 & 304 & 0 & 0 & 0 & 0 & 0 & 0 & 0 & 304 \\
\hline Gövde çeliği bedeli & 277,75 & 278 & 0 & 0 & 0 & 0 & 0 & 0 & 0 & 278 \\
\hline Gövde çeliği dikimi & 83,06 & 83 & 0 & 0 & 0 & 0 & 0 & 0 & 0 & 83 \\
\hline Sulama (İşçi ile) & 144,44 & 578 & 433 & 433 & 433 & 289 & 289 & 144 & 0 & 2.600 \\
\hline Ağaç diplerinde ot alma ve çapa & 185,30 & 556 & 371 & 371 & 0 & 0 & 0 & 0 & 0 & 1.297 \\
\hline Tek yönlü bakım sürümü & 237,24 & 474 & 474 & 474 & 474 & 237 & 237 & 237 & 0 & 2.610 \\
\hline \multirow[t]{2}{*}{ Tek yönlü diskaro çekme } & 136,76 & 274 & 274 & 274 & 274 & 137 & 137 & 137 & 0 & 1.504 \\
\hline & Ara toplam & 3311 & 1552 & 1552 & 1181 & 663 & 663 & 518 & 0 & 9.441 \\
\hline Beklenı & lerler $(\% 10)$ & 331 & 155 & 155 & 118 & 66 & 66 & 52 & 0 & 944 \\
\hline Y1llık Mal & amı (TL/ha) & 3643 & 1707 & 1707 & 1299 & 729 & 729 & 570 & 0 & 10.385 \\
\hline
\end{tabular}


Çizelge 8. Kavak ağaçlandırmalarında $3 \mathrm{~m} \mathrm{x} \mathrm{4m} \mathrm{dikim} \mathrm{sıklığ} 1$ için yıllık işlem maliyetleri

\begin{tabular}{|c|c|c|c|c|c|c|c|c|c|c|}
\hline \multirow[b]{2}{*}{ İşlemler } & \multirow{2}{*}{$\begin{array}{l}\text { Birim } \\
\text { Maliyet } \\
\text { (TL/ha) }\end{array}$} & \multicolumn{8}{|c|}{ Yaş sınıfları ve yıllık işlem maliyetleri (TL/ha) } & \multirow{2}{*}{$\begin{array}{c}\text { İşlem } \\
\text { Toplamı } \\
\text { (TL/ha) }\end{array}$} \\
\hline & & 1 & 2 & 3 & 4 & 5 & 6 & 7 & $8-12$ & \\
\hline Tam alan çapraz derin sürüm & 485,60 & 486 & 0 & 0 & 0 & 0 & 0 & 0 & 0 & 486 \\
\hline Tam alan çift yönlü diskaro çekme & 279,07 & 279 & 0 & 0 & 0 & 0 & 0 & 0 & 0 & 279 \\
\hline Dikim yerlerinin işaretlenmesi & 228,12 & 228 & 0 & 0 & 0 & 0 & 0 & 0 & 0 & 228 \\
\hline Gövde çeliği bedeli & 208,25 & 208 & 0 & 0 & 0 & 0 & 0 & 0 & 0 & 208 \\
\hline Gövde çeliği dikimi & 62,28 & 62 & 0 & 0 & 0 & 0 & 0 & 0 & 0 & 62 \\
\hline Sulama (İşçi ile) & 144,44 & 578 & 433 & 433 & 433 & 289 & 289 & 144 & 0 & 2.600 \\
\hline Ağaç diplerinde ot alma ve çapa & 138,94 & 417 & 278 & 278 & 0 & 0 & 0 & 0 & 0 & 973 \\
\hline Tek yönlü bakım sürümü & 237,24 & 474 & 474 & 474 & 474 & 237 & 237 & 237 & 0 & 2.610 \\
\hline \multirow[t]{4}{*}{ Tek yönlü diskaro çekme } & 136,76 & 274 & 274 & 274 & 274 & 137 & 137 & 137 & 0 & 1.504 \\
\hline & ara toplam & 3006 & 1459 & 1459 & 1181 & 663 & 663 & 518 & 0 & 8.950 \\
\hline & rler (\%10) & 301 & 146 & 146 & 118 & 66 & 66 & 52 & 0 & 895 \\
\hline & nı (TL/ha) & 3306 & 1605 & 1605 & 1299 & 729 & 729 & 570 & 0 & 9.845 \\
\hline
\end{tabular}

Çizelge 9. Kavak ağaçlandırmalarında 3m x 5m dikim sıklığı için yıllık işlem maliyetleri

\begin{tabular}{|c|c|c|c|c|c|c|c|c|c|c|}
\hline \multirow[b]{2}{*}{ İşlemler } & \multirow{2}{*}{$\begin{array}{l}\text { Birim } \\
\text { Maliyet } \\
\text { (TL/ha) }\end{array}$} & \multicolumn{8}{|c|}{ Yaş sınıfları ve yıllık işlem maliyetleri (TL/ha) } & \multirow{2}{*}{$\begin{array}{c}\text { İşlem } \\
\text { Toplamı } \\
\text { (TL/ha) }\end{array}$} \\
\hline & & 1 & 2 & 3 & 4 & 5 & 6 & 7 & $8-12$ & \\
\hline Tam alan çapraz derin sürüm & 485,60 & 486 & 0 & 0 & 0 & 0 & 0 & 0 & 0 & 486 \\
\hline Tam alan çift yönlü diskaro çekme & 279,07 & 279 & 0 & 0 & 0 & 0 & 0 & 0 & 0 & 279 \\
\hline Dikim yerlerinin işaretlenmesi & 182,66 & 183 & 0 & 0 & 0 & 0 & 0 & 0 & 0 & 183 \\
\hline Gövde çeliği bedeli & 166,75 & 167 & 0 & 0 & 0 & 0 & 0 & 0 & 0 & 167 \\
\hline Gövde çeliği dikimi & 49,86 & 50 & 0 & 0 & 0 & 0 & 0 & 0 & 0 & 50 \\
\hline Sulama (İşçi ile) & 144,44 & 578 & 433 & 433 & 433 & 289 & 289 & 144 & 0 & 2.600 \\
\hline Ağaç diplerinde ot alma ve çapa & 111,25 & 334 & 223 & 223 & 0 & 0 & 0 & 0 & 0 & 779 \\
\hline Tek yönlü bakım sürümü & 237,24 & 474 & 474 & 474 & 474 & 237 & 237 & 237 & 0 & 2.610 \\
\hline \multirow[t]{4}{*}{ Tek yönlü diskaro çekme } & 136,76 & 274 & 274 & 274 & 274 & 137 & 137 & 137 & 0 & 1.504 \\
\hline & ra toplam & 2823 & 1404 & 1404 & 1181 & 663 & 663 & 518 & 0 & 8.657 \\
\hline & ler $(\% 10)$ & 282 & 140 & 140 & 118 & 66 & 66 & 52 & 0 & 866 \\
\hline & 11 (TL/ha) & 3106 & 1544 & 1544 & 1299 & 729 & 729 & 570 & 0 & 9.522 \\
\hline
\end{tabular}

Çizelge 10. Kavak ağaçlandırmalarında dikim aralıklarına göre yıllık maliyetler

\begin{tabular}{crrrrr}
\hline \multirow{2}{*}{ Y1l } & \multicolumn{5}{c}{ Y1llık maliyetler (TL/ha) ve Dikim aralığ $(\mathrm{m} \times \mathrm{m})$} \\
\cline { 2 - 6 } & $3 \times 1,5$ & $3 \times 2$ & $3 \times 3$ & $3 \times 4$ & $3 \times 5$ \\
\hline 1 & 4986 & 4315 & 3643 & 3306 & 3106 \\
2 & 2115 & 1911 & 1707 & 1605 & 1544 \\
3 & 2115 & 1911 & 1707 & 1605 & 1544 \\
4 & 1299 & 1299 & 1299 & 1299 & 1299 \\
5 & 729 & 729 & 729 & 729 & 729 \\
6 & 729 & 729 & 729 & 729 & 729 \\
7 & 570 & 570 & 570 & 570 & 570 \\
$8-12$ & 0 & 0 & 0 & 0 & 0 \\
\hline Toplam & 12543 & 11465 & 10385 & 9845 & 9522 \\
\hline
\end{tabular}

\section{2. Çıktılar}

Bir ormancılık yatırımından sağlanacak odun satış gelirleri, meşcerede üretilen çeşitli ürünlerin miktarlarının, ürünün birim fiyatları çarpılması ile elde edilen gelirlerin toplamından oluşmaktadır. Kavak ağaçlandırmalarında emvalin ince uç çapı, $25 \mathrm{~cm}$ 'den kalın olanlar soymalık tomruk, $17-25 \mathrm{~cm}$ arası kerestelik tomruk, 5-17 cm yongalık odun ve $5 \mathrm{~cm}$ 'den küçük olanlar iskarta odun olarak sınıflandırılmaktadır. Birim alana düşen ağaç sayısı arttıkça, bir başka deyişıle dikim sıklığı daraldıkça, ağaçların (meşcere) ortalama çapı azalmakta, kalın çaplı ve kaliteli emval oranı düşmekte, ince çaplı emval oranı artmaktadır. Bununla birlikte dikim sıklığı daraldıkça, elde edilen toplam ürün miktarı artmaktadır. Ayrıca, elde edilen ürün miktarı, bonitet sınıfına göre de değişmektedir. Ürün miktarı, bonitet sınıfı iyileştikçe artmakta, kötüleştikçe azalmaktadır. Bu çalışmada dar dikim aralıkları uygulanarak, levha ve kağıt sektörünün talebine uygun ince çaplı kavak odunu üretimi hedeflendiği için; odun üretiminden sağlanacak gelirler, hasılat tablolarındaki yongalık odun miktarı ile yongalık odun birim fiyatı çarpılarak hesaplanmıştır. Ülkemizde kavak odunu genellikle dikili olarak pazarlanmaktadır. Kavaklığı satın alan kişi veya kurumlar, kavak odunu istihsalini (hasadını) ve taşımasını kendisi üstlenmektedir. $\mathrm{Bu}$ nedenle yongalık kavak odunu birim fiyatının belirlenmesinde dikili satış fiyatı esas alınmıştır. Yapılan piyasa araştırmaları sonucunda yongalık kavak odunu dikili birim satış fiyatının $125 \mathrm{TL} / \mathrm{m}^{3}$ olduğu takdir edilmiştir. Beş farklı klon, üç ayrı bonitet sınıfı ve beş değişik dikim aralığına göre, 12 yaş kademesi için sağlanacak gelirler Çizelge 11-15'te verilmiştir. 
Çizelge 11. I-214 klonu kavak ağaçlandırmalarında gelirler

\begin{tabular}{|c|c|c|c|c|c|c|c|c|c|c|c|c|c|c|c|}
\hline \multirow{3}{*}{ Y1l } & \multicolumn{15}{|c|}{ Yıllık gelirler (TL/ha) ve Dikim aralığı (m x m) } \\
\hline & \multicolumn{5}{|c|}{ Bonitet 1} & \multicolumn{5}{|c|}{ Bonitet 2} & \multicolumn{5}{|c|}{ Bonitet 3} \\
\hline & $3 \times 1,5$ & $3 \times 2$ & $3 \times 3$ & $3 \times 4$ & $3 \times 5$ & $3 \times 1,5$ & $3 \times 2$ & $3 \times 3$ & $3 \times 4$ & $3 \times 5$ & $3 \times 1,5$ & $3 \times 2$ & $3 \times 3$ & $3 \times 4$ & $3 \times 5$ \\
\hline 3 & 6319 & 5025 & 3736 & 3101 & 2732 & 2954 & 2320 & 1685 & 1368 & 1181 & 1286 & 1011 & 736 & 599 & 517 \\
\hline 4 & 14548 & 11779 & 9061 & 7760 & 7034 & 8888 & 7025 & 5172 & 4259 & 3728 & 5485 & 4276 & 3067 & 2466 & 2111 \\
\hline 5 & 22812 & 18831 & 14990 & 13217 & 12284 & 16029 & 12869 & 9753 & 8247 & 7392 & 11039 & 8700 & 6373 & 5226 & 4558 \\
\hline 6 & 30005 & 25167 & 20584 & 18556 & 17566 & 23209 & 18920 & 14735 & 12755 & 11670 & 17297 & 13806 & 10354 & 8675 & 7713 \\
\hline 7 & 35976 & 30547 & 25499 & 23362 & 22408 & 29742 & 24567 & 19576 & 17273 & 16062 & 23547 & 19023 & 14579 & 12448 & 11254 \\
\hline 8 & 40920 & 35064 & 29710 & 27540 & 26666 & 35429 & 29584 & 24015 & 21513 & 20258 & 29366 & 23977 & 18724 & 16245 & 14890 \\
\hline 9 & 45075 & 38884 & 33306 & 31133 & 30347 & 40311 & 33958 & 27974 & 25358 & 24113 & 34590 & 28500 & 22611 & 19878 & 18425 \\
\hline 10 & 48636 & 42161 & 36395 & 34223 & 33519 & 44513 & 37761 & 31468 & 28789 & 27581 & 39208 & 32553 & 26167 & 23252 & 21749 \\
\hline 11 & 51746 & 45014 & 39073 & 36897 & 36260 & 48163 & 41082 & 34546 & 31831 & 30672 & 43277 & 36160 & 29379 & 26337 & 24813 \\
\hline 12 & 54509 & 47533 & 41420 & 39230 & 38644 & 51371 & 44008 & 37266 & 34526 & 33418 & 46874 & 39370 & 32268 & 29132 & 27608 \\
\hline
\end{tabular}

Çizelge 12. I-45/51 klonu kavak ağaçlandırmalarında gelirler

\begin{tabular}{|c|c|c|c|c|c|c|c|c|c|c|c|c|c|c|c|}
\hline \multirow{3}{*}{ Yil } & \multicolumn{15}{|c|}{ Yıllık gelirler (TL/ha) ve Dikim aralığı (m x m) } \\
\hline & \multicolumn{5}{|c|}{ Bonitet 1} & \multicolumn{5}{|c|}{ Bonitet 2} & \multicolumn{5}{|c|}{ Bonitet 3} \\
\hline & $3 \times 1,5$ & $3 \times 2$ & $3 \times 3$ & $3 \times 4$ & $3 \times 5$ & $3 \times 1,5$ & $3 \times 2$ & $3 \times 3$ & $3 \times 4$ & $3 \times 5$ & $3 \times 1,5$ & $3 \times 2$ & $3 \times 3$ & $3 \times 4$ & $3 \times 5$ \\
\hline 3 & 5947 & 5008 & 3999 & 3408 & 2973 & 2959 & 2598 & 2199 & 1943 & 1733 & 1775 & 1624 & 1452 & 1325 & 1205 \\
\hline 4 & 12639 & 10611 & 8504 & 7346 & 6547 & 7868 & 6759 & 5601 & 4948 & 4479 & 5384 & 4733 & 4052 & 3657 & 3358 \\
\hline 5 & 19204 & 16188 & 13112 & 11477 & 10391 & 13440 & 11510 & 9545 & 8492 & 7780 & 9833 & 8561 & 7271 & 6575 & 6093 \\
\hline 6 & 25176 & 21325 & 17450 & 15442 & 14148 & 18778 & 16109 & 13437 & 12054 & 11154 & 14268 & 12407 & 10557 & 9601 & 8973 \\
\hline 7 & 30536 & 25967 & 21419 & 19112 & 17663 & 23604 & 20302 & 17038 & 15391 & 14354 & 18302 & 15935 & 13616 & 12456 & 11724 \\
\hline 8 & 35284 & 30086 & 24956 & 22398 & 20824 & 27873 & 24025 & 20257 & 18395 & 17253 & 21815 & 19024 & 16322 & 15004 & 14199 \\
\hline 9 & 39400 & 33647 & 28002 & 25222 & 23541 & 31587 & 27257 & 23047 & 20997 & 19765 & 24791 & 21644 & 18621 & 17174 & 16313 \\
\hline 10 & 42867 & 36621 & 30514 & 27529 & 25743 & 34747 & 29986 & 25373 & 23147 & 21828 & 27247 & 23794 & 20492 & 18930 & 18016 \\
\hline 11 & 45683 & 38997 & 32464 & 29281 & 27386 & 37355 & 32202 & 27212 & 24811 & 23396 & 29205 & 25481 & 21925 & 20249 & 19277 \\
\hline 12 & 47861 & 40776 & 33846 & 30462 & 28446 & 39415 & 33900 & 28548 & 25967 & 24443 & 30688 & 26719 & 22919 & 21123 & 20079 \\
\hline
\end{tabular}

Çizelge 13. Samsun klonu kavak ağaçlandırmalarında gelirler

\begin{tabular}{|c|c|c|c|c|c|c|c|c|c|c|c|c|c|c|c|}
\hline \multirow{3}{*}{ Y1l } & \multicolumn{15}{|c|}{ Y1llık gelirler (TL/ha) ve Dikim aralığ $(\mathrm{m} \times \mathrm{m})$} \\
\hline & \multicolumn{5}{|c|}{ Bonitet } & \multicolumn{5}{|c|}{ Bonitet 2} & \multicolumn{5}{|c|}{ Bonitet 3} \\
\hline & $3 \times 1,5$ & $3 \times 2$ & $3 \times 3$ & $3 \times 4$ & $3 \times 5$ & $3 \times 1,5$ & $3 \times 2$ & $3 \times 3$ & $3 \times 4$ & $3 \times 5$ & $3 \times 1,5$ & $3 \times 2$ & $3 \times 3$ & $3 \times 4$ & $3 \times 5$ \\
\hline 3 & 6757 & 5248 & 3741 & 2992 & 2550 & 4764 & 3687 & 2610 & 2073 & 1756 & 2489 & 1919 & 1349 & 1064 & 895 \\
\hline 4 & 15984 & 12589 & 9213 & 7550 & 6582 & 11794 & 9226 & 6665 & 5398 & 4655 & 7178 & 5569 & 3963 & 3164 & 2692 \\
\hline 5 & 26017 & 20779 & 15602 & 13086 & 11650 & 19719 & 15598 & 11507 & 9500 & 8337 & 13025 & 10195 & 7374 & 5979 & 5161 \\
\hline 6 & 35053 & 28340 & 21754 & 18607 & 16855 & 27110 & 21657 & 16268 & 13650 & 12156 & 18970 & 14969 & 10994 & 9040 & 7904 \\
\hline 7 & 42517 & 34725 & 27143 & 23583 & 21658 & 33407 & 26905 & 20511 & 17437 & 15711 & 24389 & 19382 & 14421 & 11998 & 10603 \\
\hline 8 & 48475 & 39919 & 31660 & 27851 & 25854 & 38568 & 31266 & 24119 & 20718 & 18839 & 29065 & 23233 & 17472 & 14676 & 13083 \\
\hline 9 & 53195 & 44097 & 35381 & 31430 & 29423 & 42745 & 34835 & 27126 & 23492 & 21514 & 32997 & 26503 & 20105 & 17019 & 15277 \\
\hline 10 & 56953 & 47466 & 38437 & 34410 & 32424 & 46130 & 37753 & 29619 & 25816 & 23775 & 36276 & 29250 & 22346 & 19034 & 17180 \\
\hline 11 & 59980 & 50204 & 40956 & 36890 & 34943 & 48895 & 40151 & 31688 & 27761 & 25679 & 39011 & 31555 & 24245 & 20755 & 18816 \\
\hline 12 & 62451 & 52454 & 43047 & 38965 & 37061 & 51177 & 42140 & 33417 & 29395 & 27287 & 41302 & 33495 & 25855 & 22223 & 20219 \\
\hline
\end{tabular}

Çizelge 14. İzmit klonu kavak ağaçlandırmalarında gelirler

\begin{tabular}{|c|c|c|c|c|c|c|c|c|c|c|c|c|c|c|c|}
\hline \multirow{3}{*}{ Yil } & \multicolumn{15}{|c|}{ Yıllık gelirler (TL/ha) ve Dikim aralığı (m x m) } \\
\hline & \multicolumn{5}{|c|}{ Bonitet 1} & \multicolumn{5}{|c|}{ Bonitet 2} & \multicolumn{5}{|c|}{ Bonitet 3} \\
\hline & $3 \times 1,5$ & $3 \times 2$ & $3 \times 3$ & $3 \times 4$ & $3 \times 5$ & $3 \times 1,5$ & $3 \times 2$ & $3 \times 3$ & $3 \times 4$ & $3 \times 5$ & $3 \times 1,5$ & $3 \times 2$ & $3 \times 3$ & $3 \times 4$ & $3 \times 5$ \\
\hline 3 & 10150 & 7980 & 5819 & 4751 & 4126 & 6936 & 5387 & 3840 & 3071 & 2616 & 4402 & 3386 & 2370 & 1863 & 1562 \\
\hline 4 & 20268 & 16256 & 12293 & 10370 & 9274 & 15422 & 12155 & 8905 & 7304 & 6369 & 10934 & 8498 & 6065 & 4856 & 4143 \\
\hline 5 & 29266 & 23913 & 18692 & 16225 & 14878 & 23994 & 19191 & 14443 & 12134 & 10813 & 18404 & 14466 & 10546 & 8611 & 7479 \\
\hline 6 & 36393 & 30198 & 24242 & 21520 & 20115 & 31437 & 25466 & 19607 & 16804 & 15240 & 25559 & 20300 & 15085 & 12532 & 11058 \\
\hline 7 & 41957 & 35234 & 28868 & 26059 & 24703 & 37582 & 30759 & 24117 & 20994 & 19300 & 31879 & 25545 & 19290 & 16257 & 14530 \\
\hline 8 & 46415 & 39331 & 32716 & 29897 & 28630 & 42640 & 35182 & 27975 & 24642 & 22885 & 37299 & 30105 & 23032 & 19633 & 17724 \\
\hline 9 & 50122 & 42755 & 35959 & 33153 & 31979 & 46875 & 38915 & 31274 & 27794 & 26007 & 41932 & 34041 & 26312 & 22630 & 20590 \\
\hline 10 & 53312 & 45696 & 38740 & 35943 & 34850 & 50500 & 42120 & 34121 & 30524 & 28721 & 45928 & 37454 & 29183 & 25273 & 23133 \\
\hline 11 & 56134 & 48281 & 41164 & 38364 & 37333 & 53672 & 44921 & 36605 & 32906 & 31090 & 49420 & 40443 & 31709 & 27605 & 25384 \\
\hline 12 & 58684 & 50597 & 43309 & 40490 & 39503 & 56500 & 47408 & 38800 & 35004 & 33171 & 52514 & 43092 & 33946 & 29673 & 27380 \\
\hline
\end{tabular}


Çizelge 15. 89.M.060 klonu kavak ağaçlandırmalarında gelirler

\begin{tabular}{|c|c|c|c|c|c|c|c|c|c|c|c|c|c|c|c|}
\hline \multirow{3}{*}{ Y1l } & \multicolumn{15}{|c|}{ Y1llık gelirler (TL/ha) ve Dikim aralığı (m x m) } \\
\hline & \multicolumn{5}{|c|}{ Bonitet 1} & \multicolumn{5}{|c|}{ Bonitet 2} & \multicolumn{5}{|c|}{ Bonitet 3} \\
\hline & $3 \times 1,5$ & $3 \times 2$ & $3 \times 3$ & $3 \times 4$ & $3 \times 5$ & $3 \times 1,5$ & $3 \times 2$ & $3 \times 3$ & $3 \times 4$ & $3 \times 5$ & $3 \times 1,5$ & $3 \times 2$ & $3 \times 3$ & $3 \times 4$ & $3 \times 5$ \\
\hline 3 & 9734 & 7576 & 5420 & 4348 & 3715 & 7053 & 5452 & 3851 & 3053 & 2579 & 4959 & 3810 & 2660 & 2086 & 1744 \\
\hline 4 & 20931 & 16506 & 12101 & 9928 & 8658 & 15653 & 12232 & 8817 & 7124 & 6126 & 11358 & 8801 & 6245 & 4974 & 4220 \\
\hline 5 & 33001 & 26306 & 19670 & 16424 & 14552 & 25268 & 19929 & 14616 & 11997 & 10466 & 18777 & 14664 & 10560 & 8524 & 7325 \\
\hline 6 & 44270 & 35574 & 26988 & 22823 & 20451 & 34515 & 27417 & 20373 & 16918 & 14918 & 26138 & 20539 & 14961 & 12205 & 10591 \\
\hline 7 & 54146 & 43762 & 33544 & 28623 & 25851 & 42799 & 34177 & 25638 & 21472 & 19076 & 32894 & 25969 & 19080 & 15686 & 13708 \\
\hline 8 & 62594 & 50798 & 39221 & 33678 & 30583 & 50002 & 40079 & 30272 & 25505 & 22780 & 38875 & 30795 & 22769 & 18825 & 16535 \\
\hline 9 & 69784 & 56797 & 44078 & 38015 & 34653 & 56203 & 45172 & 34285 & 29010 & 26009 & 44095 & 35017 & 26008 & 21592 & 19035 \\
\hline 10 & 75928 & 61924 & 48230 & 41724 & 38136 & 61547 & 49563 & 37749 & 32038 & 28801 & 48638 & 38694 & 28834 & 24008 & 21221 \\
\hline 11 & 81221 & 66335 & 51796 & 44906 & 41121 & 66178 & 53366 & 40746 & 34656 & 31213 & 52604 & 41905 & 31301 & 26117 & 23129 \\
\hline 12 & 85825 & 70166 & 54883 & 47654 & 43693 & 70225 & 56685 & 43355 & 36931 & 33307 & 56089 & 44722 & 33462 & 27963 & 24798 \\
\hline
\end{tabular}

\subsection{Ekonomik analiz bulguları}

Kavak ağaçlandırmalarının ekonomik analizinde, yatırım süresince yapılan işlem maliyetleri (Çizelge 10) ve kavak odun satışından sağlanan gelirler (Çizelge 11-15) kullanılmıştır. Dar dikim aralıklarında kurulan kavak ağaçlandırmaları için, idare süresi boyunca gerçekleşen maliyetler ve gelirlerin farkları hesaplanarak, her yaş basamağı için net nakit akımları belirlenmiştir. NBD'nin hesabında; faiz oranı $\% 8$ alınmış, yıllık maliyetlerin dönem başında yapıldığı ve gelirlerin ise dönem sonunda elde edildiği kabul edilmiştir. Klon, bonitet sınıfi, dikim aralığ ve yaşa göre oluşturulan yatırım senaryoları, net nakit akımlarına dayalı olarak yapılan ekonomik analizler ile değerlendirilmiștir. 89.M.060 klonu, I. bonitet ve 3,0m x $1,5 \mathrm{~m}\left(4,5 \mathrm{~m}^{2} /\right.$ ağaç$)$ dikim aralığı için yapılan ekonomik analiz örneği Çizelge 16'da verilmiştir.

Her bir kavak klonu için, bonitet sınıfı ve dikim aralıklarına göre elde edilebilecek en yüksek NBD ve İKO'nun ait oldukları yaşlar Çizelge 17'de verilmiştir. NBD ve İKO, bonitet sınıfı iyileştikçe ve dikim aralığı daraldıkça, daha erken yaşlarda en yüksek değerlere ulaşmaktadır. İKO değerleri, NBD'ye göre, daha erken yaşlarda en yüksek düzeye ulaşmaktadır.

Daha geniş dikim aralıklarında tesis edilen kavak ağaçlandırmalarında, faiz oranı değiştikçe, NBD'nin en yüksek düzeye ulaştığı yılların da farklılık gösterdiği (Koçer, 1999) belirlenmiştir. Benzer duyarlılık analizi, \%6, $\% 8, \% 10$ ve $\% 12$ faiz oranı kullanılarak yapılmış ve değişik faiz oranlarına göre, NBD'nin en yüksek olduğu yıllar belirlenmiş ve İKO ile karşılaştırmalı olarak Çizelge 18'de verilmiştir.

Çizelge 18 'de görüldüğü üzere, her bir seçenek için en yüksek NBD ve İKO, farklı yıllarda elde edilmektedir. Bir başka deyişle, idare süreleri her iki ölçüte göre değişmektedir. Örneğin Samsun klonu için değişik dikim aralıkları ve bonitet sınıflarına göre; NBD 8-12 ve İKO 6-11 yaşlar arasında en yüksek değerlere ulaşmaktadır. Tüm ölçütler için en yüksek değerlere, en dar dikim aralık mesafesinde ( $3 \mathrm{~m} \times 1,5 \mathrm{~m}-4,5 \mathrm{~m}^{2} /$ ağaç) ulaşılmıştır. Klonlar arasında en yüksek değerler ise, 89.M.060 klonunda elde edilmiştir. Bunun yanında, NBD hesabında kullanılan faiz oranı değiştikçe, NBD'nin en yüksek olduğu yıllar, yani ekonomik idare süreleri de değişmektedir. Bu çalışmada, faiz oranı \%6'dan \%12'ye doğru yükseldikçe, NBD'nin en yüksek olduğu yıllar düşmekte, bir başka deyişle idare süresi kısalmaktadır. NBD'deki bu değişim tüm klonlar, bonitet sınıfları ve dikim aralıkları için geçerlidir. İKO ölçütünde bir faiz oranı belirlenmeye çalışıldığı için, idare süresi değişimi söz konusu olmamaktadır.

89.M.060 klonu, I. bonitet ve 3,0m x 1,5m (4,5m²/ağaç) dikim aralığı için, NBD ve İKO gelişimleri Şekil 2'de, toplam gelir gelişimi Şekil 3'te verilmiştir. Şekil 2'de görüleceği üzere, NBD, üstten basık çan eğrisi şeklinde bir gelişim göstermekte, eğri daha düşük eğimle artmakta ve en yüksek düzeye ulaştıktan sonra yine yavaşça düşmektedir. İKO sola dayalı olarak gelişim göstermekte, NBD'ye nazaran daha erken yaşlarda hızla en yüksek düzeye ulaşmakta ve yine hızla azalmaktadır. Şekil 3 'te görüldüğü üzere, toplam para hasılası "S" eğrisi şeklinde gelişim göstermektedir. $\mathrm{Bu}$ gelişim ekonomideki toplam üretim fonksiyonuna karşılık gelmektedir (Geray, 1991; Daşdemir, 2013).

Çizelge 16. 89.M.060 klonu I. bonitet ve 3,0m x 1,5m $\left(4,5 \mathrm{~m}^{2} /\right.$ ağaç $)$ dikim aralığ için ekonomik analiz tablosu

\begin{tabular}{|c|c|c|c|c|c|c|}
\hline \multirow{4}{*}{ Yaş } & \multicolumn{4}{|c|}{ Meșcere } & \multirow{3}{*}{ NBD } & \multirow{3}{*}{ İKO } \\
\hline & \multicolumn{2}{|c|}{ Hacim } & \multicolumn{2}{|c|}{ Artım } & & \\
\hline & Ağaç & Yon.Od. & Ortalama & Cari & & \\
\hline & \multicolumn{2}{|c|}{$\left(\mathrm{m}^{3} / \mathrm{ha}\right)$} & \multicolumn{2}{|c|}{$\left(\mathrm{m}^{3} / \mathrm{ha} / \mathrm{y} 1 \mathrm{l}\right)$} & (TL/ha) & $\%$ \\
\hline 3 & 87,3 & 77,9 & 29,092 & 61,996 & -1030 & - \\
\hline 4 & 177,8 & 167,5 & 44,452 & 90,533 & 5597 & 22,03 \\
\hline 5 & 275,5 & 264,0 & 55,095 & 97,664 & 12135 & 29,93 \\
\hline 6 & 366,8 & 354,2 & 61,132 & 91,318 & 17077 & 30,32 \\
\hline 7 & 446,9 & 433,2 & 63,846 & 80,128 & 20414 & 28,81 \\
\hline 8 & 515,5 & 500,8 & 64,441 & 68,613 & 22638 & 27,03 \\
\hline 9 & 574,0 & 558,3 & 63,775 & 58,442 & 23730 & 24,97 \\
\hline 10 & 623,9 & 607,4 & 62,395 & 49,972 & 23989 & 23,05 \\
\hline 11 & 667,0 & 649,8 & 60,638 & 43,074 & 23654 & 21,33 \\
\hline 12 & 704,5 & 686,6 & 58,709 & 37,488 & 22902 & 19,80 \\
\hline
\end{tabular}


Çizelge 17. Klon, bonitet sınıfı ve dikim aralıklarına göre en yüksek İKO ve NBD ile ait olduğu yıllar

\begin{tabular}{|c|c|c|c|c|c|c|c|c|c|c|c|c|c|}
\hline \multirow{3}{*}{$\frac{\tilde{0}}{\underline{\Delta}}$} & \multirow{3}{*}{$\mathrm{m} \times \mathrm{m}$} & \multicolumn{6}{|c|}{ En Yüksek Net Bugünkü Değer (NBD) } & \multicolumn{6}{|c|}{ En Yüksek İç Kârlılık Oranı (İKO) } \\
\hline & & \multicolumn{2}{|c|}{ I. Bonitet } & \multicolumn{2}{|c|}{ II. Bonitet } & \multicolumn{2}{|c|}{ III. Bonitet } & \multicolumn{2}{|c|}{ I. Bonitet } & \multicolumn{2}{|c|}{ II. Bonitet } & \multicolumn{2}{|c|}{ III. Bonitet } \\
\hline & & TL/ha & y1l & TL/ha & y1l & TL/ha & y1l & $\%$ & y1l & $\%$ & y1l & $\%$ & y1l \\
\hline \multirow{5}{*}{$\begin{array}{c}\underset{\sim}{ \pm} \\
\stackrel{1}{D}\end{array}$} & $3 \times 1,5$ & 11369 & 9 & 9476 & 11 & 7434 & 12 & 20,48 & 6 & 16,99 & 8 & 14,31 & 9 \\
\hline & $3 \times 2$ & 9383 & 10 & 7474 & 11 & 5489 & 12 & 18,91 & 7 & 15,67 & 8 & 13,10 & 10 \\
\hline & $3 \times 3$ & 7748 & 10 & 5706 & 11 & 3704 & 12 & 17,76 & 8 & 14,36 & 9 & 11,76 & 11 \\
\hline & $3 \times 4$ & 7260 & 10 & 5119 & 12 & 2977 & 12 & 17,54 & 8 & 13,81 & 9 & 11,19 & 11 \\
\hline & $3 \times 5$ & 7269 & 11 & 4988 & 12 & 2681 & 12 & 17,68 & 8 & 13,72 & 10 & 10,96 & 12 \\
\hline \multirow{5}{*}{ 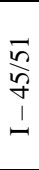 } & $3 \times 1,5$ & 8676 & 10 & 4915 & 10 & 1346 & 11 & 16,92 & 8 & 12,98 & 9 & 9,48 & 9 \\
\hline & $3 \times 2$ & 6817 & 10 & 3744 & 10 & 875 & 10 & 15,96 & 8 & 12,29 & 9 & 9,05 & 10 \\
\hline & $3 \times 3$ & 5024 & 10 & 2643 & 10 & 382 & 10 & 14,70 & 8 & 11,46 & 9 & 8,53 & 10 \\
\hline & $3 \times 4$ & 4159 & 10 & 2130 & 10 & 176 & 10 & 13,90 & 8 & 10,97 & 9 & 8,26 & 10 \\
\hline & $3 \times 5$ & 3641 & 10 & 1828 & 10 & 62 & 10 & 13,30 & 8 & 10,63 & 9 & 8,10 & 10 \\
\hline \multirow{5}{*}{$\begin{array}{l}\Xi \\
\Xi \\
\tilde{\Xi} \\
\tilde{\tilde{W}}\end{array}$} & $3 \times 1,5$ & 15431 & 9 & 10203 & 9 & 5623 & 10 & 24,36 & 6 & 18,63 & 7 & 13,63 & 8 \\
\hline & $3 \times 2$ & 11914 & 9 & 7341 & 10 & 3402 & 10 & 21,69 & 6 & 16,62 & 8 & 11,88 & 9 \\
\hline & $3 \times 3$ & 8694 & 10 & 4609 & 10 & 1288 & 11 & 18,89 & 8 & 14,11 & 8 & 9,65 & 10 \\
\hline & $3 \times 4$ & 7346 & 10 & 3366 & 10 & 309 & 11 & 17,74 & 8 & 12,65 & 9 & 8,41 & 11 \\
\hline & $3 \times 5$ & 6736 & 10 & 2731 & 11 & -213 & 11 & 17,13 & 8 & 11,91 & 9 & 7,70 & 11 \\
\hline \multirow{5}{*}{. } & $3 \times 1,5$ & 13897 & 8 & 12269 & 9 & 10094 & 10 & 26,17 & 5 & 21,63 & 6 & 17,88 & 8 \\
\hline & $3 \times 2$ & 11242 & 9 & 9364 & 10 & 7202 & 10 & 23,32 & 5 & 19,05 & 7 & 15,97 & 8 \\
\hline & $3 \times 3$ & 8879 & 9 & 6695 & 10 & 4489 & 11 & 20,73 & 6 & 16,70 & 8 & 13,44 & 9 \\
\hline & $3 \times 4$ & 8057 & 10 & 5546 & 10 & 3247 & 11 & 19,32 & 7 & 15,58 & 8 & 12,09 & 9 \\
\hline & $3 \times 5$ & 7860 & 10 & 5051 & 11 & 2604 & 11 & 19,02 & 7 & 14,96 & 8 & 11,38 & 10 \\
\hline \multirow{5}{*}{$\begin{array}{l}\stackrel{8}{8} \\
\text { ¿̦ } \\
\sum_{\infty}\end{array}$} & $3 \times 1,5$ & 23989 & 10 & 17328 & 10 & 11381 & 11 & 30,32 & 6 & 23,97 & 6 & 18,59 & 8 \\
\hline & $3 \times 2$ & 18537 & 10 & 12811 & 10 & 7826 & 11 & 27,51 & 6 & 21,27 & 7 & 16,36 & 8 \\
\hline & $3 \times 3$ & 13230 & 10 & 8375 & 10 & 4314 & 11 & 23,50 & 6 & 18,09 & 8 & 13,26 & 9 \\
\hline & $3 \times 4$ & 10734 & 10 & 6271 & 11 & 2609 & 11 & 21,35 & 7 & 16,18 & 8 & 11,39 & 9 \\
\hline & $3 \times 5$ & 9381 & 10 & 5104 & 11 & 1637 & 11 & 20,15 & 8 & 14,88 & 8 & 10,24 & 10 \\
\hline
\end{tabular}

Çizelge 18. İKO ve değişik faiz oranlarına göre NBD'nin en yüksek olduğu yıllar

\begin{tabular}{|c|c|c|c|c|c|c|c|c|c|c|c|c|c|c|c|c|}
\hline \multirow{3}{*}{ 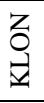 } & \multirow{3}{*}{ 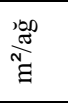 } & \multicolumn{15}{|c|}{ NBD ve İKO'nun en yüksek olduğu yıl } \\
\hline & & \multicolumn{5}{|c|}{ I. Bonitet } & \multicolumn{5}{|c|}{ II. Bonitet } & \multicolumn{5}{|c|}{ III. Bonitet } \\
\hline & & $\% 6$ & $\% 8$ & $\% 10$ & $\% 12$ & İKO & $\% 6$ & $\% 8$ & $\% 10$ & $\% 12$ & $\dot{\mathrm{I}} \mathrm{KO}$ & $\% 6$ & $\% 8$ & $\% 10$ & $\% 12$ & $\dot{\mathrm{I} K O}$ \\
\hline \multirow{5}{*}{$\begin{array}{l}\underset{J}{J} \\
\stackrel{1}{ }\end{array}$} & 4,5 & 11 & 9 & 9 & 9 & 6 & 12 & 11 & 10 & 9 & 8 & 12 & 12 & 11 & 10 & 9 \\
\hline & 6,0 & 11 & 10 & 9 & 9 & 7 & 12 & 11 & 10 & 9 & 8 & 12 & 12 & 11 & 10 & 10 \\
\hline & 9,0 & 12 & 10 & 9 & 9 & 8 & 12 & 11 & 10 & 10 & 9 & 12 & 12 & 11 & 11 & 11 \\
\hline & 12,0 & 12 & 10 & 9 & 9 & 8 & 12 & 11 & 11 & 10 & 9 & 12 & 12 & 12 & 11 & 11 \\
\hline & 15,0 & 12 & 11 & 10 & 9 & 8 & 12 & 12 & 11 & 10 & 10 & 12 & 12 & 12 & 11 & 12 \\
\hline \multirow{5}{*}{$\begin{array}{l}\bar{n} \\
\frac{n}{8} \\
\dot{1} \\
\sim\end{array}$} & 4,5 & 11 & 10 & 9 & 8 & 8 & 11 & 10 & 10 & 9 & 9 & 11 & 11 & 9 & 9 & 9 \\
\hline & 6,0 & 11 & 10 & 9 & 8 & 8 & 11 & 10 & 10 & 9 & 9 & 11 & 10 & 9 & 9 & 10 \\
\hline & 9,0 & 11 & 10 & 9 & 9 & 8 & 11 & 10 & 10 & 9 & 9 & 11 & 10 & 10 & 9 & 10 \\
\hline & 12,0 & 11 & 10 & 9 & 9 & 8 & 11 & 10 & 10 & 10 & 9 & 11 & 10 & 10 & 9 & 10 \\
\hline & 15,0 & 11 & 10 & 9 & 9 & 8 & 11 & 10 & 10 & 9 & 9 & 11 & 10 & 10 & 9 & 10 \\
\hline \multirow{5}{*}{ 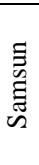 } & 4,5 & 10 & 9 & 8 & 8 & 6 & 10 & 9 & 9 & 8 & 7 & 11 & 10 & 9 & 9 & 8 \\
\hline & 6,0 & 10 & 9 & 9 & 8 & 6 & 11 & 10 & 9 & 8 & 8 & 12 & 10 & 10 & 9 & 9 \\
\hline & 9,0 & 11 & 10 & 9 & 8 & 8 & 11 & 10 & 9 & 9 & 8 & 12 & 11 & 10 & 9 & 10 \\
\hline & 12,0 & 11 & 10 & 9 & 9 & 8 & 11 & 10 & 9 & 9 & 9 & 12 & 11 & 10 & 9 & 11 \\
\hline & 15,0 & 12 & 10 & 10 & 9 & 8 & 12 & 11 & 10 & 9 & 9 & 12 & 11 & 10 & 9 & 11 \\
\hline \multirow{5}{*}{. } & 4,5 & 10 & 8 & 8 & 7 & 5 & 11 & 9 & 8 & 8 & 6 & 12 & 10 & 9 & 9 & 8 \\
\hline & 6,0 & 10 & 9 & 8 & 7 & 5 & 11 & 10 & 9 & 8 & 7 & 12 & 10 & 10 & 9 & 8 \\
\hline & 9,0 & 11 & 9 & 8 & 8 & 6 & 11 & 10 & 9 & 8 & 8 & 12 & 11 & 10 & 9 & 9 \\
\hline & 12,0 & 11 & 10 & 9 & 8 & 7 & 11 & 10 & 9 & 9 & 8 & 12 & 11 & 10 & 9 & 9 \\
\hline & 15,0 & 11 & 10 & 9 & 8 & 7 & 12 & 11 & 10 & 9 & 8 & 12 & 11 & 10 & 9 & 10 \\
\hline \multirow{5}{*}{ 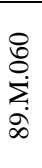 } & 4,5 & 11 & 10 & 9 & 8 & 6 & 12 & 10 & 9 & 9 & 6 & 12 & 11 & 10 & 9 & 8 \\
\hline & 6,0 & 11 & 10 & 9 & 8 & 6 & 12 & 10 & 9 & 9 & 7 & 12 & 11 & 10 & 9 & 8 \\
\hline & 9,0 & 11 & 10 & 9 & 9 & 6 & 12 & 10 & 10 & 9 & 8 & 12 & 11 & 10 & 9 & 9 \\
\hline & 12,0 & 12 & 10 & 9 & 9 & 7 & 12 & 11 & 10 & 9 & 8 & 12 & 11 & 10 & 9 & 9 \\
\hline & 15,0 & 12 & 10 & 10 & 9 & 8 & 12 & 11 & 10 & 9 & 8 & 12 & 11 & 10 & 9 & 10 \\
\hline
\end{tabular}




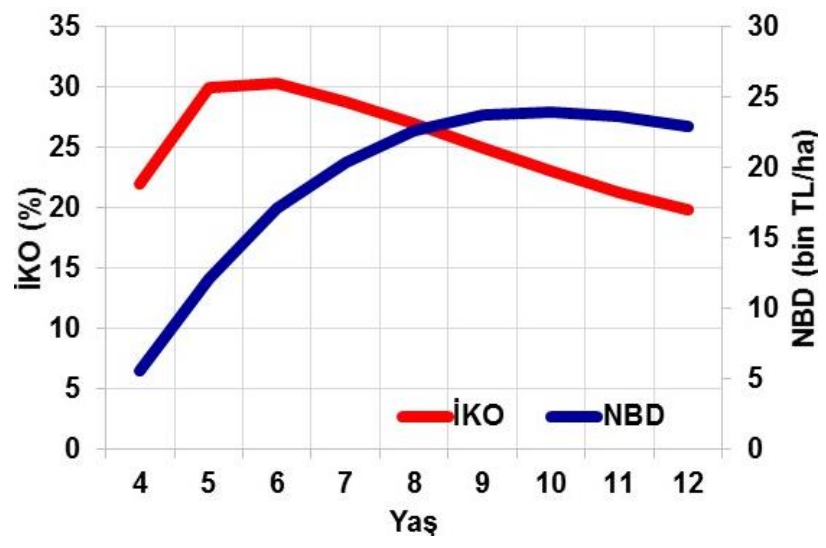

Şekil 2. Kavak ağaçlandırmalarında NBD ve İKO geliş̧imi

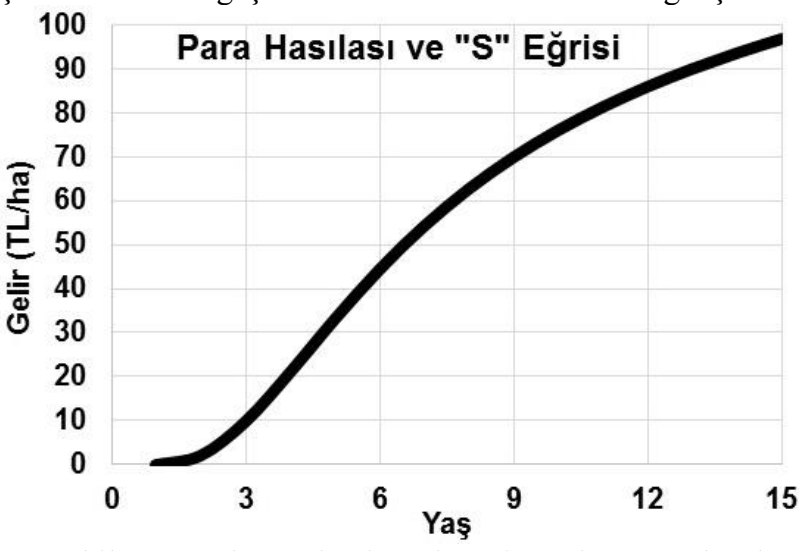

Şekil 3. Kavak ağaçlandırmalarında toplam para hasılası gelişimi

\section{Tartışma, sonuç ve öneriler}

20. yüzyılın ikinci yarısından itibaren odun hammaddesine olan talebin artması ve bu talebin doğal ormanlardan karşılanmasının mümkün olmadığının anlaşılması üzerine, kitlesel üretime yönelik ince çaplı odun üretilen endüstriyel ağaçlandırmalar yaygınlaşmış, üretilen hammaddeyi kullanan endüstri kolunun kapasitesi giderek büyümüş ve buradan elde edilen yeni ürünlerin kullanımı insan yaşamında yer almıştır. Kavak başta olmak üzere, çam, okaliptüs, söğüt gibi hızlı gelişen ağaç türleri endüstriyel ağaçlandırmalarda kullanılmaya başlanmıştır.

Ağaç başına daha fazla yaşam alanının düştüğü ormancılık çalışmalarında, uzun sayılabilecek idare sürelerinde, daha kalın çaplı ve gövde kalitesi yüksek hammadde üretilmektedir. Bu üretim modeli artan talebin karşılanmasına yeterli olamamaktadır. Bu nedenle, birim alandan daha fazla odun hammaddesinin daha kisa idare sürelerinde sağlanabileceği üretim modellerinin geliştirilmesi gerekmektedir. Kitlesel üretim miktarını artırmaya yönelik olarak, dar dikim aralıklarında tesis edilen ağaçlandırmaların rolü önem kazanmıştır. Ayrıca, endüstriyel ağaçlandırmalarda, daha fazla artım ve büyüme gösteren genetik yönden üstün nitelikli dikim materyali kullanılması, çalışmaların işgücü yerine mekanizasyona dayalı yürütülmesi sonucunda, sermaye yoğun teknolojiye geçilmiş olmaktadır.

Dikim materyali, diğer fiziki ve biyolojik değişkenleri aynı olan bir arazide, dikim aralıklarını değiştirerek, farklı işletme amaçları doğrultusunda değişik idare sürelerine sahip işletmecilik yapılabilecektir. Bu nedenle, dikim aralığ değişkeni orman işletmeciliğinde idare sürelerini değiştirme olanağı vermektedir. $\mathrm{Bu}$ çalışmada, daha kısa idare sürelerinde, kitlesel olarak ince çaplı emvalin elde edildiği üretim modellerinin geliştirilmesi amaçlanmıştır. Kağıt ve levha endüstrisinin talebine uygun, ince çaplı ve kitlesel kavak odunu üretiminin tasarlandığ 1 bu tür ağaçlandırmalarda, sadece yongalık odun ürün çeşidinin elde edilebileceği, soymalık ve kerestelik tomruğun üretilmeyeceği kabul edilmiştir.

Ağaçlandırmalarda maliyetler, yürütülen işlemlere ve kullanılan materyal maliyetlerine göre değişmektedir. İşlemlerin birim maliyetleri tüm kavak klonları için aynı olduğundan, maliyetler kavak klonlarına göre değişmemektedir. Ayrıca, arazi kira maliyetleri, alternatif maliyetler, arazinin rantı vb. unsurlar hesaplanmadığı için, maliyetler bonitet sınıflarına göre değişmemektedir. Dolayısıyla maliyetler klon çeşidi ve bonitet sınıfına göre değil, beş dikim aralığı için ayrı ayrı belirlenmiştir. Toplam maliyet, en yüksek en dar dikim aralığında $(3 \mathrm{~m} \times 1,5 \mathrm{~m})$ $12543 \mathrm{TL} / \mathrm{ha}$, en düşük en geniş dikim aralığında (3m x 5m) $9522 \mathrm{TL} /$ ha olarak belirlenmiştir (Çizelge 10).

Kavak klonu, bonitet sınıfı, dikim aralığı ve yaşa göre elde edilecek yongalık odun miktarları, ürünün birim fiyatıyla çarpılarak para hasılaları belirlenmiştir. Ülkemizde kavak ağaçlandırmalarında yaygın olarak kullanılan I-214 Melez Kavağı ve Samsun Kavağı klonlarının, ürün birim satış fiyatları arasında farklılık bulunmamaktadır. Dolayısıyla ürün birim fiyatlarının kavak klonlarına göre değişmediği kabul edilmiştir (Çizelge 11-15).

Para hasılaları, elde edilen odunun miktarına paralel olarak, dikim aralığı daraldıkça ve bonitet sınıfı iyileştikçe artmakta ve dikim aralığı genişledikçe ve bonitet sınıfı kötüleştikçe azalmaktadır. Para hasılası en yüksek 89.M.060 klonunda, en düşük I-45/51 klonunda elde edilmektedir.

Ekonomik analizler idare süresi boyunca gerçekleşen maliyetlere ve idare süresi sonunda elde edilen gelirlere göre yapılmıştır. Ekonomik analiz sonuçlarına göre, dar dikim aralıklarında kurulan kavak ağaçlandırmalarının yapılabilir yatırımlar olduğu ortaya konulmuştur.

İzmit Orman Fidanlığındaki deneme ağaçlandırmalarının 11. yaştaki deneysel değerlerine göre, İKO en yüksek 89.M.060 klonunda, en düşük I-45/51 klonunda elde edilmiştir. Aynı çalışmada geniş ve dar dikim aralıkları da karşılaştırılmış ve tüm klonlarda ve sıklıklarda, dar dikim aralıklarının İKO değerlerinin, geniş dikim aralığına nazaran daha yüksek olduğu belirlenmiştir. Örneğin, 11. yaşta I-214 klonunda $3 \mathrm{~m}$ x $2 \mathrm{~m}$ dikim aralığında \%22,4 İKO’ya ulaşılırken, geniş dikim aralığında $6 \mathrm{~m} \times \mathrm{m}$ için en yüksek İKO \%19,0 olarak elde edilmiştir (Kara, 2017).

İKO, NBD'den daha erken yaşlarda en yüksek düzeye ulaşmaktadır. Bonitet sınıfı iyileştikçe ve dikim aralığı daraldıkça, NBD ve İKO'nun en yüksek değere ulaştığı yaşlar, bir başka deyişle ekonomik idare süreleri kısalmaktadır. Tüm klonlarda NBD ve İKO, I. bonitet sınıfında ve 4,5 m²/ağaç dikim aralığında en yüksek düzeye ulaşmaktadır. NBD ve İKO, en yüksek 89.M.060 klonunda, en düşük I-45/51 klonunda belirlenmiştir. En yüksek NBD, 89.M.060 klonunda 10. yaşta sağlanmakta olup 23989 TL/ha kadardır. En yüksek İKO ise, yine 89.M.060 klonunda 6. yaşta \%30,32 olarak hesaplanmıştır (Çizelge 17). 
Adapazarı ve Düzce ovalarında uydu görüntülerine göre, kavak arazilerinde \%95 oranında I-214 klonunun kullanıldığı ortaya konulmuştur (Ercan vd., 2002). Karakaya (2010) tarafından yürütülen bir çalışmada, Sakarya'daki kavak üreticilerinin \%64'ünün Samsun klonunu tercih ettiği belirlenmiştir. Bozkurt vd. (2017) Samsun yöresindeki üreticilerin tamamının Samsun klonunu seçtiklerini ifade etmişlerdir. Samsun klonunun daha hızlı büyümesi, piyasada talep görmesi ve düzgün gövdeli olması nedeniyle, yetiştiriciler tarafindan tercih edildiği ve zaman içerisinde klon tercihlerinin değişebildiği belirlenmiştir. Samsun klonu ile I-214 klonunun maliyetlerinin aynı olmasına rağmen, üreticinin Samsun klonundan daha fazla gelir elde ettiği için, bu klonu tercih ettiği belirlenmiştir (Bozkurt vd., 2018). Kavak ağaçlandırmalarında kullanılan klonlar zaman içerisinde değişmekte, yetiştiriciler daha hızlı büyüyen ve daha çok gelir getiren klonlara yönelmektedir. Bu nedenle, ARGE çalışmalarıyla, yeni kavak klonlarının geliştirilmesi büyük önem taşımaktadır.

89.M.060 klonu halen tescili yapılmış kavak klonlarına göre daha yüksek büyüme ve kârlılık performansı göstermektedir. Bir çalışmada, 89.M.060 klonunun, diğer ticari klonlara göre zararlılara karşı daha dirençli olduğu ortaya konulmuştur (Uluer vd., 2008). Ayrıca, 89.M.060 klonunda teknolojik özellikler bakımından tatminkâr sonuçların (Akkılıç, 2019) alındığı belirlenmiştir. Sayılan bu nedenlerle, 89.M.060 klonunun ulusal ve uluslararas1 tescili yapılmalıdır.

Çalışmada kullanılan dört ticari klon başka ülkelerde selekte edilerek ülkemize getirilmiştir. 89.M.060 klonu, Kavak ve Hızlı Gelişen Orman Ağaçları Araştırma Enstitüsü, Genetik ve Islah Araştırmaları Bölümü tarafindan, 1989 yılında yapılan $P$. deltoides melezlerinin çaprazlamaları sonucunda ülkemizde selekte edilmiş bir klondur (Tunçtaner, 2008; Tunçtaner vd., 1992). Bu nedenle, tüm fikri ve mülkiyet haklarının ülkemize ait olması, bu klonun önemini artırmaktadır.

Günümüzde giderek artan çevresel bilinç ve duyarlılık nedeniyle, fosil kökenli yakıtlara ve petrol türevli plastik malzemelere olan tepki, son y1llarda giderek büyümekte ve kullanımının azaltılması gündeme gelmektedir. Yenilenebilir bir hammadde kaynağı olarak, ileri teknoloji ile üretilmiş odun kökenli ürünlerin, bazı petrol türevi ürünleri ikame edebileceği öngörülmektedir. $\mathrm{Bu}$ talebin karşılanmasında başta kavak olmak üzere, hızlı gelişen orman ağacı türleri önemli bir rol üstlenecektir. Dolayısıyla ülkemiz ormancılık sektörünün politikalarını ve stratejilerini, beklenen hedeflere göre oluşturması gerekmektedir. ARGE birimlerinin de belirlenen stratejilere göre çalışmalarını yürütmelerinde ve gözden geçirmelerinde yarar bulunmaktadir.

Önümüzdeki yıllarda biyoenerji ve biyoyakıt sektöründe önemli gelişmelerin olacağı öngörülmekte ve özellikle geliş̧miş ülkeler bu sektöre ciddi destekler sağlamaktadır. Bu konuda ARGE yatırımlarına büyük önem verilmektedir. Dolayısıyla endüstriyel enerji ağaçlandırmalarının yaygınlaştırılması bir zorunluluk olarak karşımıza çıkabilecektir. Biyoenerji üretiminde kullanılabilecek odun hammaddesi, diğer orman ürünleri sanayi kuruluşlarının kullanamadığı standartlardaki çok ince çaplı emval, odun artığı vb. niteliktedir. Bu nedenle, dikim aralıkları daha da daraltılarak ve dolayısıyla idare süreleri (2-5 yıl) daha da kısaltılarak, enerji sektörünün talebine uygun kitlesel odun hammaddesi üretim modellerinin geliştirilmesi söz konusu olabilecektir.

Kavak ağacı odunlarından sağlanabilecek etanol miktarı teorik olarak hesaplanmış ve elde edilen değerler literatür değerleri ile karşılaştırılmış, biyoetanol üretiminde kullanılacak uygun ağaç türlerinin seçiminde, üretim miktarı ve idare süreleri önemli parametreler olarak ortaya çıkmış ve kavak ağacının oldukça yüksek performansa sahip olduğu belirlenmiştir. Teorik biyoetanol verimi ve üretim göstergeleri dikkate alındığında, kavak ağacının biyoetanol üretimi için uygun bir materyal olduğu ortaya konulmuştur (Gürboy vd., 2008). Endüstriyel enerji ağaçlandırmalarının geliştirilmesinde, üretim ve işletme teknikleri bakımından uygun olan kavak cinsi kullanılabilecektir. Ayrıca kavak yanında söğüt türleri de ülkemiz için önemli firsatlar sunmaktadır.

Son 50 yılda ülkemizin demografik yapısında önemli değişiklikler olmuştur. Bunun yanında, endüstriyel tarımdaki bilimsel gelişmeler ve yatırımlar, aynı üretim düzeyi için daha az araziye ihtiyaç duyulmasına yol açmaktadır. Anılan nedenlerle, tarım yapılan araziler daralmakta ve bazı tarım arazileri atıl hale gelmektedir. Sonuç olarak, diğer ülkelerdeki gelişmelere paralel olarak, tarım sektörüne nazaran daha az emek yoğun sektör olan "Endüstriyel Ăgaçlandırmalar", "Çiftlik Ormancılı̆̆ı", "A ̆gaç Tarımı" vb. olarak adlandırılan uygulamaların devreye girmesi beklenmelidir. Kitlesel odun üretim amaçlı bu yatırımların bir bölümünde kavak ve hızlı gelişen ağaç türleriyle tesis edilen endüstriyel ağaçlandırmaların yaygınlaşması kaçınılmazdır. Gelişme potansiyeli bulunan sektör için stratejik kararlar alınması, mevzuatta düzenlemeler yapılması ve ülkemize özgü teknik ve finansal modellerin geliştirilmesi gerekmektedir.

\subsection{Endüstriyel kavak ăgaçlandırma yatırımlarının değerlendirilmesinde ölçüt seçimi}

Odun üretim amaçlı ormancılık çalışmalarının sürdürülebilirliği, gerçekleşecek üretim düzeyine ve ticari başarıya bağlıdır. Dolayısıyla seçilen amaca uygun olarak, ağaç türünün veya klonunun, sıklığın ve idare sürelerinin isabetli belirlenmesi gerekmektedir. Ormancılık ve ağaçlandırma yatırımlarının ticari açıdan değerlendirilmesinde NBD ve İKO ölçütleri ön plana çıkmaktadır. Aynı ağaç türü (kavak klonu), bonitet sınıfı ve dikim aralığı için, NBD ve İKO değerleri farklı yıllarda en yüksek düzeye ulaşmakta ve dolayısıyla birbirinden farklı idare süreleri belirlenmektedir. Bu nedenle, odun üretim amaçlı ormancılık yatırımlarının ticari kârlılık açısından değerlendirilmesinde, ölçüt seçimi büyük önem taşımaktadır. Her iki ölçüt de kendi içerisinde olumlu ve olumsuz yanları barındırmaktadır.

Faiz oranının seçimi NBD ölçütünün zayıf noktalarından birisidir. Ormancılık ve ağaçlandırma çalışmaları uzun bir yatırım ve işletme süresini zorunlu kıldığı için, bir idare süresi içerisinde faiz oranları değişiklik gösterebilmektedir.

NBD ölçütüne göre yapılan ekonomik analizlerde, faiz oranı \%8 olarak alınmıştır. Ancak, faiz oranındaki değişimlerin idare süresi üzerindeki etkilerini görmek amaciyla, 3 farklı faiz oranıla ( $\% 6, \% 10$ ve $\% 12)$ NBD ve en yüksek olduğu yıllar, yani idare süreleri belirlenmiştir. Yapılan analizler sonucunda, faiz oranı değiştikçe NBD'nin en yüksek olduğu yılların ve idare sürelerinin değiştiği görülmüştür. Bu çalışma kapsamında elde edilen bulgulara 
göre, NBD'nin hesabında kullanılan faiz oranı yükseldikçe idare süreleri kısalmaktadır. NBD'nin hesabında kullanılan faiz oranı IKKO'ya yaklaştıkça, NBD'ye göre belirlenen idare süresi, İKO ile belirlenen idare süresine yaklaşmaktadır (Çizelge 18). NBD'nin hesabında İKO'nun kullanılması durumunda, her iki ölçüt için de aynı idare süreleri elde edilecektir. NBD'nin hesabında faiz oranı sıfır alındığında ise, meşcere hacmi ve dolayısıyla toplam gelir her yıl arttığ için, NBD de artacaktır. Böyle bir durumda, en yüksek NBD düzeyine, toplam meşcere hacminin azalmaya başladığ yılda, yani biyolojik idare süresi sonunda ulaşılmış olacaktır. Oysa, İKO ölçütünde bir faiz oranı belirlenmeye çalışıldığı için, idare sürelerinde değişim söz konusu değildir.

NBD ve İKO eğrileri, odun üretimi miktarı açısından hacim artımları ile karşılaştıııldığında, genel ortalama artım (GOA) ve yıllık cari artım (YCA) eğrilerine benzemektedir. GOA eğrisi NBD eğrisine ve YCA eğrisi ise, İKO eğrisine paralellik göstermektedir. Büyüme kanuniyetlerine göre, YCA eğrisi hızla artmakta, GOA'dan önce en yüksek düzeye ulaştıktan sonra hızla düşmekte ve GOA'nın en yüksek olduğu yaşta GOA eğrisiyle kesişmektedir. GOA, yayvan görünümlü çan eğrisi şeklinde bir gelişim göstermektedir (Şekil 2). Elde edilen brüt para hasılaların gelişimi de toplam meşcere hacim gelişimine karşılık gelmektedir (Şekil 3).

Odun üretim amaçlı bir yatırımda, İKO'dan daha düşük bir oranın kullanıldığ 1 NBD hesabına göre idare süresinin belirlenmesi durumunda, idare süreleri daha uzun belirlenmiş olmaktadır. Üstelik bu yol izlendiği takdirde, yapılan yatırımın kârlılık oranının daha düşük olması göze alınmaktadır. Örneğin, I. bonitet sınıfı, $4,5 \mathrm{~m}^{2} /$ ağaç sıklık ve 89.M.060 klonunda, en yüksek İKO \%30,32 olup idare süresi 6 yıldır. Fakat en yüksek NBD değerine 10. yılda ulaşılmaktadır (Çizelge 16, İKO \%23,05). Anılan yatırım seçeneğinde idare süresinin 10 yıl olarak belirlenmesi durumunda, 4 yıl boyunca daha düşük bir oranda kârlılığa razı olunmaktadır.

NBD ölçütü ile kitlesel odun üretim amaçlı endüstriyel ormancılık ve ağaçlandırma yatırımlarının değerlendirilmesinde, değişik faiz oranlarına göre farklı idare süreleri belirlenmektedir. Bunun yanında, İKO ile belirlenenden daha uzun olan idare süreleri nedeniyle, yatırımın kârlılık oranı daha düşük olmaktadır. Bu nedenlerle, odun üretim amaçlı ormancılık yatırımlarının değerlendirilmesinde İKO ölçütü kullanılmalıdır.

\section{2. İdare sürelerinin belirlenmesi}

Orman işletmeciliğinde idare süresi, aynı yaşlı ve maktalı ormanlarda, meşcerenin tesisinden hasadına kadar geçen üretim süresidir (Eraslan, 1982). Daşdemir (2013) ise idare süresini; "bir ormanı planlarken üretim düzeyinden başlayarak, para hasılatına, masraflara, iş yoğunluğuna, ürünün arzına ve fiyatına, üretim riskine ve işletmenin kârlılığına kadar bir dizi faktöre çok yönlü etkileri olan bir planlama aracı" olarak tanımlamaktadır. Ok (1997) ise, idare süresinin sadece bir işletme sınıfina ilişkin değerlendirilmemesini, alınan kararın işletmenin tamamını ilgilendirdiğini, bu nedenle de idare süresinin her bir işletme sınıfına göre ayrı ayrı, fakat işletmenin tamamı için geçerli ekonomik ve sosyal sonuçlar göz önünde bulundurularak belirlenmesi gerektiğini belirtmektedir. Ormancılıkta işletme amaçları, işlevleri ve değişik niteliklere göre, tek bir idare süresinden söz edilmemekte, farklı idare süreleri tanımlanmaktadır. Örneğin teknik, biyolojik, doğal, fiziki veya ekonomik idare süreleri yanında, Türker (2008) ve Daşdemir (2013), sosyo-ekonomik idare süreleri olarak, en yüksek ülke ekonomisi verimliliği idare süresi, en yüksek katma değer idare süresi gibi tanımlamalar yapmışlardır.

İdare süresi değişik fiziki ve ekonomik değişkenlere göre belirlenirken, kesime olgunluk yaşı veya olgunluk yaşı, tek ağaç veya meşcere için söz konusu olmaktadır. Doğal orman alanlarında gerçekleştirilen işletmecilikte süreklilik ilkesi temel alınmaktadır. Ancak, amacı sadece odun hammaddesi üretmek olan kavak ağaçlandırmalarının değerlendirilmesinde, süreklilik ilkesinin her zaman geçerli olmadığı, tek bir amaç ve dönem esas alındığı için, idare süresi ile kesime olgunluk süresi aynı olmaktadır.

Bonitet sınıfı idare süresini etkilemektedir. Bonitet sınıfı, yaşa göre ağaçların büyümeleri, artımları ve bu artımların en yüksek olduğu yaş üzerinde etkili olmaktadır. Bonitet sınıfı değiştikçe idare süresi de değişmektedir. Örneğin aynı işletme amacı, ağaç türü/klonu ve dikim sıklığ 1 için, bonitet sınıfı iyileştikçe idare süresi kısalmaktadır. Ancak, potansiyel bonitet üzerinde etkili olmak olanaksızdır. Toprak kültürlerinde, kullanılan materyal ve yapılması gerekli kültür ve bakım işlemlerinin düzeyine göre aktüel bonitet değişebilmektedir. Örneğin yeterli sulama işlemi yapılmayan bir kavaklığın potansiyel boniteti değişmemesine rağmen, aktüel bonitetinin yüksek olması beklenemez.

Ülkemizde doğal ormanlardaki değişik ağaç türleri için yapılan çoğu hasılat çalışmalarında, ormanın normal sıklık derecelerinde olduğu kabul edilmiş ve sıklık ihmal edilmiştir. $\mathrm{Bu}$ nedenle, bonitet sınıflarına göre düzeyi değişmekle birlikte, ağaçların yaşa göre çap büyümesi üzerinde etkili olan sıklık değişkeni dikkate alınmamıştır. Kavak ağaçlandırmalarında yedi farklı dikim sıklığı için "değişken sıklık hasılat tabloları" elde edilmiştir (Birler, 1986). Benzer bir çalışma, yedi farklı dikim aralığına göre Eucalyptus camaldulensis Dehn. ağaçlandırmaları için yapılmıştır (Birler vd., 1995). Yeşil (1992) tarafından, değişik meşcere sıklıklarının dikkate alındığı müdahale görmüş doğal kızılçam meşcereleri için bir hasılat çalışması yapılmıştır.

Meşcere sıklığı, bonitet sınıfında olduğu gibi idare süresini etkilemektedir. Meşcere sıklığı veya ağaçlandırma alanları için dikim aralığı, ağaçların çap gelişimi ve dolayısıyla, hacim artımları ve bu artımların en yüksek olduğu yaş üzerinde etkili olmaktadır. Ağaç başına düşen yaşam alanı daraldıkça, meşcere ortalama çapı azalmakta, daha ince çaplı emval üretilmekte ve fakat birim alandaki ağaç sayısı arttı̆̆ için, toplam meşcere hacmi yani toplam üretim düzeyi artmaktadır. Bununla birlikte, ağaçlar arasındaki rekabet nedeniyle, cari çap artımı, geniş dikim aralığı uygulanan meşcerelere nazaran daha erken yaşlarda en yüksek miktarlara ulaştığından fiziki idare süresi kısalmaktadır. Ağaç başına düşen dikim aralığ genişledikçe, ağaçlar arasındaki rekabet giderek azaldığ için, daha kalın çaplı ve kaliteli ürün elde edilmekte, birim alandaki ağaç sayısı azaldığından toplam üretim miktarı düşmekte, hacim artımları daha geç yıllarda en yüksek düzeye ulaşmakta ve fiziki idare süreleri uzamaktadır. Geniş dikim aralıklarındaki kavak ağaçlandırmalarında, bonitet sınıfına göre değişmekle birlikte, idare süreleri 8-15 yıl aralığında olmaktadır. Oysa daha dar dikim aralığının uygulandığı kavak ağaçlandırmalarında, idare süresileri 
daha kısa olmakta ve 5-12 yıl aralığında değişmektedir. Çok daha dar dikim aralığı uygulandığı takdirde, 2-5 yıl aralığında değişen idare sürelerinde, örneğin enerji sektörünün talebine uygun çok daha ince çaplı emval üretilebilecektir. $\mathrm{Bu}$ nedenle, enerji sektörünün talebine uygun üretim yapabilmek için, bazı biyokütle çalışmaları, dikim sıklığının çok dar ve idare süresinin çok daha kısa olması esasına göre yürütülmüştür (Dillen vd., 2009; Sara vd., 2009).

Ormancılık yatırımlarında idare sürelerinin değiştirilmesi konusunda, dikim aralığg değişkeni, çok önemli bir olanak sunmaktadır. Aynı kavak klonu ile değişik dikim aralıklarını kullanarak, 2 yıldan 15 yıla kadar değişen idare sürelerinde, değişik nitelikte odun hammaddesi üreterek kavak işletmeciliği yapma olanağı bulunmaktadır.

Ülkemizdeki odun üretim amaçlı doğal ormanların işletilmesinde, idare süreleri belirlenirken, en yüksek odun hasılatının sağlanması kuramı kapsamında, GOA miktarları ve bunların en yüksek olduğu yaşlar dikkate alınmaktadır. Oysa YCA'nın da idare süresinin üzerindeki etkisinin bilinmesi gerekmektedir. Bonitet sınıfi kötüleştikçe ve dikim aralığı genişledikçe, GOA ve YCA daha sonraki yıllarda en yüksek düzeye ulaşmakta (Birler, 1986, Birler vd., 1995, Birler vd., 1996, Usta, 1985, Usta, 1990, Yeşil, 1992) ve böylece fiziki idare süreleri uzamaktadır. YCA, ekonomi bilimindeki marjinal fiziksel üretim fonksiyonuna benzemektedir (Daşdemir, 2013) ve toplam meşcere hacim fonksiyonunun birinci dereceden türevidir. Dolayısıyla, idare sürelerinin belirlenmesinde GOA dikkate alındığı için, meşcerenin daha erken yaşlarda göstermiş olduğu büyüme ve kârlılık performansı göz ardı edilmiş olmaktadır.

İKO ve YCA sola dayalı olarak gelişim göstermekte ve daha erken yaşlarda hızla en yüksek düzeye ulaşarak yine hızla düşmektedir. GOA ise, İKO ve YCA'nın en yüksek düzeye ulaştığı yaşlardan sonra en yüksek düzeye ulaşmaktadır. 89.M.060 klonu, I. bonitet ve 3,0m x 1,5m $\left(4,5 \mathrm{~m}^{2} /\right.$ ağaç$)$ dikim aralığı için, İKO, YCA ve GOA Şekil 4 'te verilmiştir. Böylece, idare süresinin GOA miktarının en yüksek olduğu yaşa göre seçilmesi durumunda, kârlılığın daha düşük olduğu işletmecilik yapılmış olmaktadır (Çizelge 16, 8. yaş).
$\mathrm{Bu}$ çalışma kapsamında klonlar, bonitet sınıfları ve dikim aralıkları için, İKO ölçütüne göre belirlenen idare süreleri Çizelge 19'da özetlenmiştir.

Odun üretimine dayalı orman işletmeciliğinin ve özellikle endüstriyel kavak ağaçlandırmalarının ticari yatırımlar olması ve en yüksek düzeyde ekonomik faydanın sağlanması amaçlandığı için, idare sürelerinin belirlenmesinde fiziki ölçütlerin yerine, ekonomik ölçütlerin dikkate alınması daha uygun olacaktır. NBD ölçütünün proje büyüklüğünden etkilenme, faiz oranı seçimindeki zayıflıklar ve daha az kârlılık oranına razı olunması gibi nedenlerle, endüstriyel ağaçlandırma yatırımlarının değerlendirilmesinde kullanılması sakınca oluşturmaktadır. Dolayısıyla, odun üretim amaçlı ormancılık yatırımlarının ticari başarı bakımından değerlendirilmesinde, alternatiflerin birbirleriyle karşılaştırılmasında ve idare sürelerinin belirlenmesinde, proje büyüklüğünden etkilenmeyen ve faiz oranı seçimi riski taşımayan İKO ölçütünün kullanılması daha uygundur.

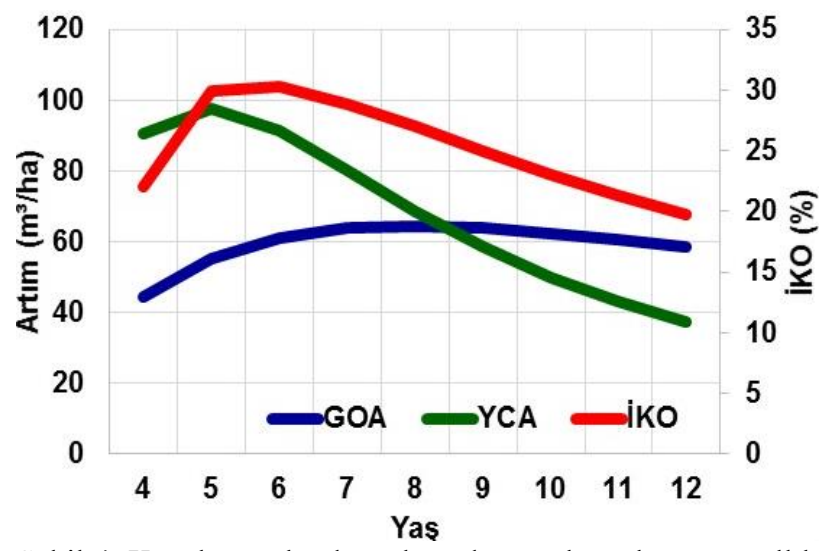

Şekil 4. Kavak ağaçlandırmalarında genel ortalama ve yıllık cari artımlar ile İKO gelişimi

Çizelge 19. İKO ölçütüne göre belirlenmiş olan idare süreleri

\begin{tabular}{|c|c|c|c|c|c|c|}
\hline \multirow{2}{*}{$\begin{array}{c}\text { Dikim } \\
\text { aralıkları } \\
(\mathrm{m} \times \mathrm{m})\end{array}$} & \multirow{2}{*}{$\begin{array}{c}\text { Bonitet } \\
\text { sinıfi }\end{array}$} & \multicolumn{5}{|c|}{ Dikim aralıkları, kavak klonları ve ağaçlandırmaların yaşına göre idare süreleri (Yıl) } \\
\hline & & 89.M.060 & Samsun & Izmit & $\mathrm{I}-214$ & $\mathrm{I}-45 / 51$ \\
\hline \multirow{3}{*}{$3,0 \times 1,5$} & $\mathrm{I}$ & 6 & 6 & 5 & 6 & 8 \\
\hline & II & 6 & 7 & 6 & 8 & 9 \\
\hline & III & 8 & 8 & 8 & 9 & 9 \\
\hline \multirow{3}{*}{$3,0 \times 2,0$} & I & 6 & 6 & 5 & 7 & 8 \\
\hline & II & 7 & 8 & 7 & 8 & 9 \\
\hline & III & 8 & 9 & 8 & 10 & 10 \\
\hline \multirow{3}{*}{$3,0 \times 3,0$} & I & 6 & 8 & 6 & 8 & 8 \\
\hline & II & 8 & 8 & 8 & 9 & 9 \\
\hline & III & 9 & 10 & 9 & 11 & 10 \\
\hline \multirow{3}{*}{$3,0 \times 4,0$} & I & 7 & 8 & 7 & 8 & 8 \\
\hline & II & 8 & 9 & 8 & 9 & 9 \\
\hline & III & 9 & 11 & 9 & 11 & 10 \\
\hline \multirow{3}{*}{$3,0 \times 5,0$} & I & 8 & 8 & 7 & 8 & 8 \\
\hline & II & 8 & 9 & 8 & 10 & 9 \\
\hline & III & 10 & 11 & 10 & 12 & 10 \\
\hline
\end{tabular}




\section{Açıklama}

Bu makale; OGM, Kavak ve Hızlı Gelişen Orman Ağaçları Araştırma Enstitüsü Müdürlüğü tarafından 2002 - 2019 yılları arasında yürütülen IZTT - 357 (5306) numaralı "Dar Dikim Aralıklarında Kurulan Kavak (P.x euramericana ve P. deltoides Klonları) Ağaçlandırmalarının Hasılatı ve Ekonomisi" adlı araștırma projesi sonuç raporunun bir bölümünün özetinden oluşmaktadır. Makalede atıfta bulunulan özgün hasılat tabloları, şekil ve çizelgeler, araștırma projesi sonuç raporundan elde edilebilir.

\section{Kaynaklar}

Akkaya, M., Ok, K., Koç, M., Akseki, İ., Akkaş, M. E., 2020. Türkiye'de ithal odun hammaddesinin sektörel kullanımı. Isparta Uygulamalı Bilimler Üniversitesi Türkiye Ormancilık Dergisi 21 (3):279 - 293.

Akkılıç, H., 2019. Farklı bölgelerde, farklı dikim aralıkları ile tesis edilmiş bazı kavak klonlarının teknolojik özellikleri. TMMK IX. Genel Kurul Toplantıs1, 17 - 18 Nisan 2019, Afyon.

Birler, A. S., 1986. "I-214" Melez Kavağı Ağaçlandırmalarında Hasılat Araştırmaları. Kavak ve Hızlı Gelişen Yabancı Tür Orman Ağaçları Araștırma Enstitüsü, İzmit.

Birler, A. S., 2010. Türkiye'de Kavak Yetiştirme. Kavak ve Hızlı Gelişen Tür Orman Ağaçları Araştırma Enstitüsü Yayını, 223 s., İzmit.

Birler, A. S., Yüksel, Y., Diner, A. 1989. I-214 Melez Kavak ağaçlandırma Ekonomisi. Kavak ve Hızlı Gelişen Tür Orman Ağaçları Araştırma Enstitüsü Teknik Bülten No: 145, İzmit.

Birler, A. S., Koçar, S., Avcıŏlu, E., Diner, A., Gürses, K., Gülbaba, G., 1995. Okaliptüs (Eucalyptus camaldulensis Dehn.) Ağaçlandırmalarında Hacim ve Kuru Madde Hasılatı. Kavak ve Hızlı Gelişen Tür Orman Ağaçları Araştırma Enstitüsü Teknik Bülten No: 171, İzmit.

Birler, A. S., Diner, A., Koçar, S. 1996. Melez Kavak (P.x euramericana (Dode) Guinier cv. "I-214") Klonunda Kitle Üretimi. Kavak ve Hızlı Gelişen Tür Orman Ağaçları Araștırma Enstitüsü Teknik Bülten No: 179, İzmit.

Bozkurt, A., Daşdemir, İ., Karakaya, S., Şahin, H. A., 2017. Samsun İli Kavak Üreticilerinin Sosyo-Ekonomik Yapısı, Sorunları, Beklentileri ve Çözüm Önerileri. Kavak ve Hızlı Gelişen Orman Ağaçları Araştırma Enstitüsü, Proje Sonuç Raporu, İzmit.

Bozkurt, A., Daşdemir, İ., Karakaya, S., Sahin, H. A., 2018. Sakarya İli Kavak Üreticilerinin İş Doyumunu Etkileyen Faktörler. Kavak ve Hızlı Gelișen Orman Ağaçları Araştırma Enstitüsü, Proje Sonuç Raporu, 62 s., İzmit.

Daşdemir, İ., 2013. Ormancılık İșletme Ekonomisi. ISBN: 978605-60882-8-5, Bartın Ü. O.F. Yayın No: 10/6, 407 s., Bartın.

Dedebaş, T., 2019. Ağaç bazlı panel sektörü, tespit ve çözüm yolları. TMMK IX. Genel Kurul Toplantıs1, 17 - 18 Nisan 2019, Afyon.

Dillen, S., Maron, N., Sabatti, M., 2009. Relationships among productuvity determinants in two hybrid poplar families grown during tree years at two contrasting sites. Tree Physiolgy s1 13.

Ercan, M., Uluer, K., Selek, F., 2002. Uzaktan Algilama Verilerinden Yararlanılarak, Adapazarı ve Düzce Ovalarında Melez Kavak Dikili Alanların Envanteri. Kavak ve Hızlı Gelişen Orman Ağaçları Araştırma Enstitüsü, Müdürlük Yayın No: 232, İzmit.

Eraslan, 1982. Orman Amenajmanı. İ. Ü. Orman Fak. Yayın No: 3010/318, İstanbul.

FAO, 2018. Yearbook of Forest Products, 2012 - 2016. ISBN 97892-5-130642-0, ISSN: 1020-458X, FAO, 358p, Rome.
FAO, 2019. Yearbook of Forest Products, 2013 - 2017. ISBN 978 92-5-131717-4, ISSN: 1020-458X, FAO, 436p, Rome.

Geray, U., 1986. Planlama. İstanbul Üniv. Orman Fak., Yüksek Lisans Ders Notları, İstanbul, 118s.

Geray, U., 1991. Ekonomi. İ. Ü. Yayın No: 3633, Orman Fak. Yayın No: 408, ISBN 975-404-209-8, İstanbul.

Gürboy, B., Bayramoğlu, M., Koçer, S., 2008. Türkiye'de lignoselülozik biyokütle kaynağı olarak kavağın biyoetanol potansiyelinin değerlendirilmesi. VII. Ulusal Temiz Enerji Sempozyumu, UTES'2008 17-19, Aralık 2008, İstanbul.

Kara, M. S., 2017. Farklı klon ve siklıklardaki kavak ağaçlandırmalarının ekonomik analizi. İ. Ü. Fen Bilimleri Enstitüsü Yüksek Lisans Tezi, 106 s., İstanbul.

Karakaya, S., 2010. Sakarya İli Kavak Üreticilerinin SosyoEkonomik Yapısı ve Başarı Düzeylerini Etkileyen Faktörler. Kavak ve Hızlı Gelişen Orman Ağaçları Araştırma Müdürlüğü, Teknik Bülten No:209, 126 s, İzmit.

Koçer, S., 1999. Ülkemizde Kavakçıllığın Geliştirilmesinde Yeni Finansman Olanakları. Kavak ve Hızlı Gelişen Tür Orman Ağaçları Araștırma Enstitüsü Teknik Bülten No: 190, İzmit.

Koçer, S., 2006. Endüstriyel ağaçlandırma yatırımlarının önemi, gerekliliği ve mali analizi (Sahil Çamı örneği). Ormancılıkta Sosyo - Ekonomik Sorunlar Kongresi, 26 - 28 Mayıs 2006, Cankırı.

Koçer, S. Şener, G., Kara, S. M., 2020. Dar Dikim Aralıklarında Kurulan Kavak (P.x euramericana ve P. deltoides Klonlar1) Ağaçlandırmalarının Hasılatı ve Ekonomisi. Kavak ve Hızlı Gelişen Orman Ağaçları Araştırma Enstitüsü Müdürlüğü, Proje Sonuç Raporu, Proje No: IZT-357(5306)/2002-2019, İzmit.

OGM, 2019. 2019 Yil1 Birim Fiyatları https://www.ogm.gov.tr/ekutuphane/Sayfalar/Mevzuat/Talimat lar.aspx, Erişim: 22.10.2019.

Ok, K., 1997. Aynıyaşlı ormanlarda kesim düzeninin ekonomik analizi. İ. Ü. Fen Bilimleri Enstitüsü Doktora Tezi, 228 s, İstanbul.

Sara, B., Gianni, F., Minotta, G., 2009. Identification of the main environment and cultivation factors affecting biomass productions in short rotation coppice plantations through stepwise regression analysis. 17th Biomass Conference, Volume I: 186-193, Hamburg.

Tunçtaner, K., 2008. Kavaklarda Genetik Islah ve Seleksiyon. Kavak ve Hızlı Gelișen Tür Orman Ağaçları Araștırma Enstitüsü, Çeşitli Yayınlar Serisi No: 19, 268s, İzmit.

Tunçtaner, K., Tulukçu, M., Toplu, F., 1992. Kavaklarda Yapay Melezleme Çalışmaları (1987 - 1990). Kavak ve Hızlı Gelişen Yabancı Tür Orman Ağaçları Araştırma Enstitüsü, Teknik Bülten No: 1992-2/156, 26s, İzmit.

Türker, M. F., 2008. Ormancıllk İșletme Ekonomisi. ISBN: 978605-602-95-0-9, Derya Kitabevi, 255 s., Trabzon.

Uluer, U., Selek, F., Özay, F. S., Karakaya, A., 2008. Bazı Kavak Klonlarının Pas Mantarına (Melampsora allii - populina Kleb.) Karșı Dirençlerinin Araștırılması. Kavak ve Hızlı Gelișen Tür Orman Ağaçları Araştırma Enstitüsü Teknik Bülten No: 207, 25.s, İzmit.

UNIDO, 1977. Endüstri projelerini değerlendirme el kitabı. (çeviri) Birleșmiş Milletler Sınai Kalkınma Teşkilatı (UNDP/UNIDO) Yayın No: 77/01, Ankara.142 s.

Usta, H. Z., 1985. Populus x euramericana (Dode) Guinier cv "I214" Melez Kavak Klonunda Dikim Aralıkları Denemeleri. Kavak ve Hızlı Gelișen Tür Orman Ağaçları Araştırma Enstitüsü Y1llık Bülten No: 21, s. 135 - 179, İzmit.

Usta, H. Z., 1990. Kızılçam (Pinus brutia Ten.) Ağaçlandırmalarında Hasılat Araştırmaları. Ormancılık Araştırma Enstitüsü Yayınları, Teknik Bülten No: 219.

Yeșil, A., 1992. Değișik sıklık ve bonitetdeki Kızılçam meşcerelerinin yaşa göre gelişimi. Doktora Tezi, İstanbul. 